\title{
Review of Remote Sensing for Land Administration: Origins, Debates, and Selected Cases
}

\author{
Rohan Mark Bennett ${ }^{1,2, *\left(\mathbb{D}, \text { Mila Koeva }^{3}(\mathbb{D}) \text { and Kwabena Asiama }\right.}{ }^{4}$ (D) \\ 1 Swinburne School of Business, Law, and Entrepreneurship, Swinburne University of Technology, \\ Hawthorn, VIC 3122, Australia \\ 2 Kadaster, The Netherlands Cadastre, Land Registry and Mapping Agency, \\ $7311 \mathrm{KZ}$ Apeldoorn, The Netherlands \\ 3 Faculty of Geo-Information Science and Earth Observation (ITC), University of Twente, \\ 7514 AE Enschede, The Netherlands; m.n.koeva@utwente.nl \\ 4 Geodetic Institute (GIH), Leibniz University Hannover, 30167 Hannover, Germany; \\ asiama@gih.uni-hannover.de \\ * Correspondence: rohanbennett@swin.edu.au
}

Citation: Bennett, R.M.; Koeva, M.; Asiama, K. Review of Remote Sensing for Land Administration: Origins, Debates, and Selected Cases. Remote Sens. 2021, 13, 4198. https://doi.org/ $10.3390 / \mathrm{rs} 13214198$

Academic Editor: Parth Sarathi Roy

Received: 22 September 2021

Accepted: 14 October 2021

Published: 20 October 2021

Publisher's Note: MDPI stays neutral with regard to jurisdictional claims in published maps and institutional affiliations.

Copyright: (c) 2021 by the authors. Licensee MDPI, Basel, Switzerland. This article is an open access article distributed under the terms and conditions of the Creative Commons Attribution (CC BY) license (https:// creativecommons.org/licenses/by/ $4.0 /)$.

\begin{abstract}
Conventionally, land administration-incorporating cadastres and land registration-uses ground-based survey methods. This approach can be traced over millennia. The application of photogrammetry and remote sensing is understood to be far more contemporary, only commencing deeper into the 20th century. This paper seeks to counter this view, contending that these methods are far from recent additions to land administration: successful application dates back much earlier, often complementing ground-based methods. Using now more accessible historical works, made available through archive digitisation, this paper presents an enriched and more complete synthesis of the developments of photogrammetric methods and remote sensing applied to the domain of land administration. Developments from early phototopography and aerial surveys, through to analytical photogrammetric methods, the emergence of satellite remote sensing, digital cameras, and latterly lidar surveys, UAVs, and feature extraction are covered. The synthesis illustrates how debates over the benefits of the technique are hardly new. Neither are well-meaning, although oft-flawed, comparative analyses on criteria relating to time, cost, coverage, and quality. Apart from providing this more holistic view and a timely reminder of previous work, this paper brings contemporary practical value in further demonstrating to land administration practitioners that remote sensing for data capture, and subsequent map production, are an entirely legitimate, if not essential, part of the domain. Contemporary arguments that the tools and approaches do not bring adequate accuracy for land administration purposes are easily countered by the weight of evidence. Indeed, these arguments may be considered to undermine the pragmatism inherent to the surveying discipline, traditionally an essential characteristic of the profession. That said, it is left to land administration practitioners to determine the relevance of these methods for any specific country context.
\end{abstract}

Keywords: photogrammetry; aerial imagery; UAV; HRSI; lidar; artificial intelligence

\section{Introduction}

In the context of this work, 'land administration' incorporates the concepts of cadastre and land registration and is understood as the process of recording, securing, and disseminating information about land tenure, value, use, and development, within a jurisdiction [1]. Its core purposes are to support land rights securitisation, land market governance, credit access, fair land taxation, and responsible spatial planning, amongst other societal concerns [2]. 'Photogrammetry' incorporates methods and tools for extracting multi-dimensional geospatial information from images needed for mapping activities [3] (for further origins and etymology, see Polidori L. 'Words as tracers in the history of science and technology: the case of photogrammetry and remote sensing'. Geo-spatial Information 
Science. 2021, 24, 167-177). 'Remote sensing' is the process of scanning or monitoring the physical characteristics of a terrestrial surface, measuring the emitted radiation at a distance [4]. Both photogrammetry and remote sensing have grown out of photographic mapping and aerial survey traditions.

The driver for the work is to further consolidate arguments for the use of photogrammetric and remote sensing methods in the domain of land administration [5], particularly when used in a complementary fashion with ground-based surveying methods. Whilst photogrammetric and remote sensing methods are used within the field in some contexts, arguably, they are heavily underutilised, especially given the amount of imagery data and collection ability now available at a relatively low cost, with vast spatial coverage, and good temporal qualities [6]. Compared to other related fields, such as construction and agriculture, rates of the application of image-based mapping, at scale, remain low in the land administration domain. The argument can be made for both developed and developing contexts, where field-based data collection techniques prevail in many circumstances [1]. Overall, it is argued that the strong bias towards the use of ground methods alone is driven by the existing land administration practitioner community for reasons of financial expedience and industry inertia [6].

The justification for the work is that such a review has never been undertaken, at least in the contemporary era. The opportunity to undertake this work is now available due to the increased availability of archival journals and records, thanks to digitisation, scanning, and online availability. This enables a more complete understanding of the historical developments within the domain to be presented to a new audience, thereby informing future developments, and creating a better appreciation of the close relationship between the fields of land administration photogrammetry and remote sensing, which have often operated disparately. Accordingly, the structure of this paper is as follows. First, an outline of the approach and methods used for the review is provided. Second, the presentation of the review results, using a chronological approach, commencing from the 1700s and swiftly moving into the 1900s, using a combination of theme and decade, is provided. Third, a summary of the synthesis of developments is delivered in a concise fashion. Finally, conclusions relevant for contemporary discourse on the use of photogrammetry and remote sensing in the land administration field are articulated.

\section{Materials and Methods}

To enable the achievement of the objective to provide a comprehensive review of photogrammetry and remote sensing applied in land administration, a research synthesis methodology was applied [7]. Couched somewhere within-or between-the positivist, constructivist, and pragmatic research paradigms [8], this approach seeks critical analysis of a scoped body of literature, synthesizing the results, to deliver a previously unrecognised model or description. The approach is used widely in the domain of land administration [9], amongst others, particularly since the 2000s, due to the greater availability of historical sources, and an increasing amount of empirical literature more generally [10].

For this review, an unlimited starting date, and up to August 2021 for the conclusion date, were selected. This rather expansive epoch enabled the most comprehensive coverage of documents, and was still considered to be achievable in terms of available time and resources. For practical purposes, the initial search and selection of documents was conducted by decade, commencing with pre-1900s, and subsequently 1900-1909, 1910-1919, and so on, up until 2021.

Using [10] as a model, the repositories examined included those exploited in other research syntheses from the land administration domain, including Google Scholar, Scopus, Science Direct, and the OICRF website (International Office of Cadastre and Land Records (See: https:/ / www.oicrf.org/search, accessed between July and August 2021 website, a searchable index and repository maintained by the Dutch Cadastre, Land Registry and Mapping Agency (Kadaster). As in [10], non-Scholar Google searches were completed alongside the academic database searches, so that relevant grey literature, from industry 
and governments, could also be captured. In general, the grey literature was given less weighting. An important limitation of this approach is that non-English language documents received less attention, primarily documents written in French and German, which were certainly prominent languages in terms of developments in the late 1800s, the 1900s, and between the world wars. It is left for other scholars to fill these gaps, yet it is expected that a similar trajectory in technological developments, albeit based on different country experiences, will be observed.

Specific search terms and search string combinations included 'land administration', 'land registry', 'land registration', 'cadastre', 'cadastral boundaries', 'cadastral surveying', 'land surveying', 'land parcel', 'property', 'monuments', 'photography', 'balloon survey', 'remote sensing', 'photogrammetry', 'photogrammetric methods', 'aerial photography', 'aerial survey', 'high-resolution satellite imagery' (and variations, e.g., VHRSI), and 'indirect methods' - and later 'UAVs', 'RPAS', 'lidar', 'SAR-radar', 'oblique imagery', 'feature extraction' and 'pictometry'. During this process, it was determined that different terms increased and decreased in popularity over time. This fact was considered when conducting the searches. The approach produced thousands of returned results; however, snowballing [11] and expert knowledge was used to determine the final constellation of approximately 300 relevant articles. The authors took the opportunity to present this bibliography in the references section. Whilst making the paper more cumbersome, it was felt that this complete provision of sources increases the utility of the paper for readers and invites the reader to undertake their own explorations.

The review, critique, and synthesis were initially undertaken and reported in chronological order, and the results are presented in Section 3 to Section 8. The further synthesis of salient ideas and development of an overarching synthesis model was then undertaken and is presented in Section 9.

\section{First Forays (1700s to 1909)}

Within the scope of a single journal paper, attempting a complete analysis of all converging developments in land administration and photographic methods prior to the 1900 s is at best overly ambitious and perhaps naïve. That said, to not attempt to include coverage would constitute a disservice to the pioneering work. Here, a humble attempt is made to provide a potted overview of key developments and examples.

\section{1. $1700 \mathrm{~s}$}

Whilst the contemporary view that photographic approaches, applied to land administration, only developed significant impetus in the 20th century, certainly the potential for the developing science of photography, applied to land surveying and mapping, was well recognised in the 19th century. The European Age of the Enlightenment of the 17th and 18th centuries spurred the development and application of many of the applied sciences, including those tools and techniques relating to geometry and land surveying, particularly as the era of colonisation advanced, and there was an increasing need to map new territories. Here, the works and treatises of Martindale [12], Love [13], Breaks [14], and Laybourne [15], amongst others, are remarkable, ushering in the emerging era of more wide-scale accurate plot measurement via the use of theodolites, chain, and other plain surveying methods.

\section{2. $1800 \mathrm{~s}$}

Similar works, out of the United Kingdom, North America, and other colonies, followed into the early part and middle part of the 19th century: Ainslie [16] provides an example out of the Scottish Enlightenment and the subsequent industrialisation period.

Likewise, from the same motivations came the first texts on developments and practical guides on photography and the Daguerreotype $[17,18]$. However, it was not until the middle and later part of the 19th century that applications of photography in the domains of land surveying and mapping were first documented. Tissandier [19], writing in 1877, 
hypothesises (alongside explanations of the science, tools, and applications of photographs) that future applications of photography will prominently include 'land surveying'. He goes on to explain how it was already considered "possible to combine surveying with photography" by placing "a camera on a land surveyor's stand, fixing it upon an axis so it can be turned around in any direction ..." "enabling the creation of complete panorama of the landscape. Surely, herein lies a very early envisioning for 'Cyclorama' and Google's 'Street View', that would appear well over a century later. Meanwhile, Reed [20], writing in 1889, provides a historical account of developments across that century, from the use of perspective drawings for topographic mapping, to the development of telemetrography in the 1850s, through to the development of photographic surveying in the 1860s in France. An outline of various methods, including via plane, via cylindric, via radial, and balloon photography is provided (although the latter was more readily used for survey reconnaissance purposes). Thomas [21] details similar examples in geographic and engineering surveys out of America. Devillle [22] provides similar techniques as applied in Canada (for a comprehensive visual overview, see: https://www.isprs.org/society/history/100Jahre.pdf, accessed on 18 October 2021). The work of the Uniting Kingdom's Ordnance Survey is also noteworthy in this period. Although not using photogrammetric methods in the field, as early as the 1840 s, it was using photographic methods, specifically photozincography, to produce and reproduce topographic maps of various scales [23-25] (note, in the 1970s, Mumford would provide a full synthesis of these developments. See Mumford I. Lithography, photography and photozincography in English map production before 1870. The Cartographic Journal. 1972 Jun 1;9(1):30-6). The same techniques were later applied to map production in India [26], apparently with great success. The approach was used in Sweden, and presumably elsewhere across Europe [27].

By the end of the century, the techniques of aerial photographic methods were recognized as legitimate [28] for surveying, and were being taken advantage of, particularly in more rugged and inaccessible landscapes. Flemer [28], writing in 'Science', explains the 'phototopography' method being used in Alaska. Whilst it would only be in the following century that these innovations truly impacted land administration functions, thanks to the work of these early photographic pioneers, the vision, tools, and methods were now in place.

\section{3. $1900 \mathrm{~s}$}

Moving into the first decade of the 1900s, there appear only limited relevant works (recognizing, however, that works in French are not included in this review, for which there appears to be numerous works on 'cadastre' during this period), although several are truly worth noting. Writing in 1908 [29], the remarkable Vivian Thompson, apparently later killed during World War 1 [30], picks up from the work of Deville [22] to provide a full detailed account of the tools and techniques involved in Stereo-Photo Surveying (Figure 1). Perhaps of most novelty is the discussion on the relative merits of the method versus plane-table surveying, in terms of accuracy, cost, and time- -a discourse quickly settled upon by others [31], and that was to be oft returned to throughout the century, as more photogrammetric advances emerged. Thompson explains how: "The objective of photographic surveying is to map the detail of a triangulated area at minimum expenditure of time and labour in the field, and at a total cost so far below that involved in plane-tabling as to warrant the sacrifice of that that high degree of accuracy attenable in good plane-tabling". He also clarifies: "... it might appear that photographic surveying is necessarily less accurate than plane-tabling. This is not the case; but, to attain the same degree of accuracy in detail" ... "the plotting would be so tedious" and "less economical". He suggests that photographic surveying has not proved more popular due to it being wrongly applied: the economic benefits only increase as the scale of the map decreases, and the ruggedness of the landscape increases. He summarises that small-scale contour maps ( 2 inches $=1$ mile) are the most economical, taking one-tenth or one-fifth of the time as compared to ground-based techniques. 

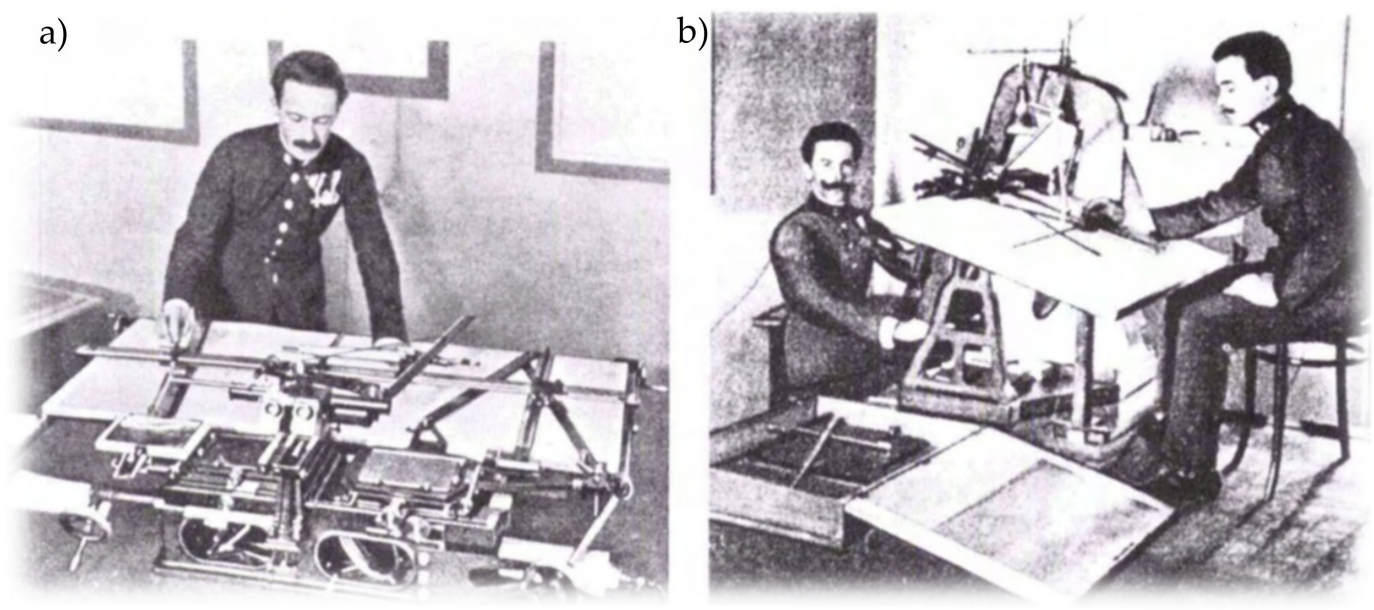

Figure 1. The first mechanical stereographs, developed in parallel by (a) Van Orel of Austria and (b) Vivian Thomson of England (Adapted from https://www.asprs.org/wp-content/uploads/pers/1985journal/jul/1985_jul_919-933.pdf, accessed on 18 October 2021), had a significant impact on cadastral mapping in later decades.

That said, notwithstanding the prioritisation of topographic mapping over cadastral mapping in the British Isles, the use of photographic methods in cadastral work is not countenanced at this point: frontier and railway reconnaissance work were the prime applications. Indeed, Johnston [32,33] confirms the emerging distinction between geographic, topographic, and cadastral mapping, in terms of the practitioners and techniques employed. He also suggests that within a generation, most parts of the world will have been accurately mapped topographically - as in France, Germany, and the United Kingdom-and that mapping of the landscape is likely to become a regular or repeating activity, rather than a singular occurrence. Importantly, he recognises that the great expenses in resources and time used to map those jurisdictions may be avoided using emerging techniques, and presumably, photographic methods are front of mind here.

\section{New Era Begins (1910 to 1929)}

\subsection{0s}

Major developments in aerial surveying and photogrammetric mapping techniques occurred in the 1910s, largely driven by the Great War, or World War I, 1914-1918 [34] (Figures 2 and 3). The strategic importance of these developments with regard to the conflict-including aerial photography, sound-ranging, and flash-spotting-meant that they remained largely unpublished until after the war [35]. Thereafter, the different developments from the German, British and French perspectives were eventually shared [36,37]. The close combat nature of trench warfare demanded large-scale and highly accurate topographic maps, but also made conventional mapping techniques impossible. Remote techniques, such as resection and aerial survey, were therefore developed out of necessity.

The use of these new and enhanced techniques was then considered for non-war applications. It was duly recognised that large-scale topographic maps could be readily produced, even for cadastral applications [38,39], although the role of the surveyor for more detailed work remained recognised: “One may safely sum up the situation by saying that the aeroplane is already a valuable instrument for both exploration and accurate survey in flat country, and that it should not be long before its application will be universal, and one may venture to predict that in survey, as in other matters, the Great War will mark the beginning of a new era." The analysis here included cost breakdowns and comparisons between ground methods and aerial survey [39], summing at between 5 and 15 pounds sterling, per square mile, at 1/2500 scale, for aerial survey, and anywhere from 10 to 1100 pounds sterling per square mile at $1 / 2500$ for a ground survey. In terms of costs, the new methods are argued to abolish significant costs around traverses, bookings, calculations, and plotting, and the associated fieldwork expenses. Instead, these dense survey networks could be 
replaced with trig stations every 1-2 miles. With regard to speed, examples from Italian work in Damascus are pointed to: "three Italian engineers took two years to produce a 1/4000 map of Damascus with its winding streets; an aeroplane produced a picture in a few hours, a rough-scale map or mosaic in a day, and an accurately finished map on $1 / 2500$ could be completed with triangulation within a month of starting".

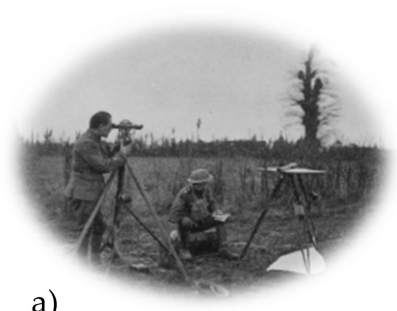

a)

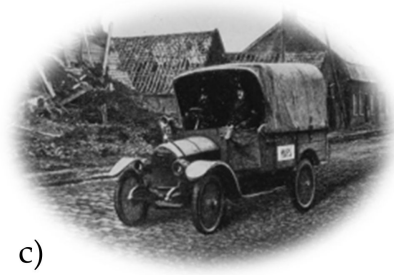

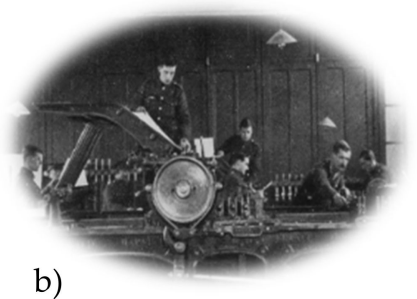

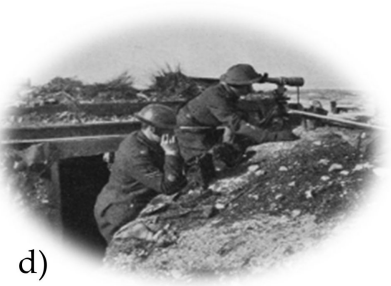

Figure 2. By the 1920s, new-era cadastral mapping was exploiting World War I aerial photography advances to produce higher-accuracy parcel maps (adapted from [36]). (a) Triangulation with a Lucas signalizing lamp; (b) printing office of a field survey battalion; (c) map distribution by car; (d) first establishment of flash-spotting post in a trench after an advance.

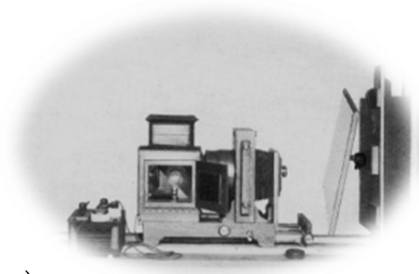

a)

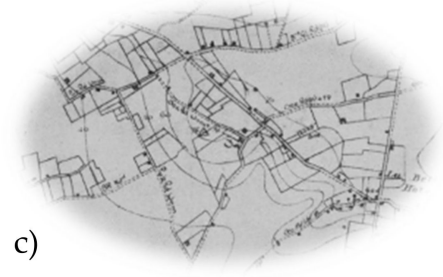

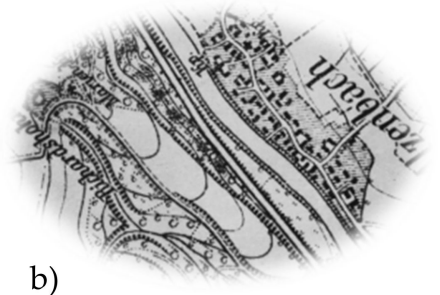

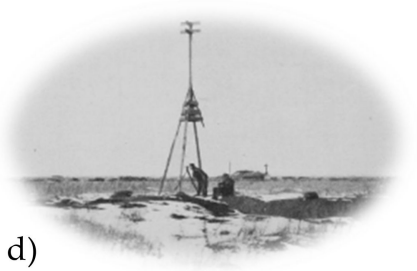

Figure 3. New-era techniques for mapping from aerial photographs. (a) Enlarging lantern and tilting copying board for the rectification of aerial photographs; (b) extraction of 1:25,000 maps from photos; (c) map for revision by plane-table and aerial photograph; (d) German triangulation signal (adapted [34,36]).

The role of non-mapping experts undertaking work is also declared: "Anyone with local knowledge, not necessarily a surveyor, can take this 1/2500 mosaic and go over the ground collecting names, defined plots of ground, wells, etc."

So positive was the idea that the approach was considered and planned for the entirety of Palestine during the British mandate; however, it was never implemented (see: Gavish D. An account of an unrealized aerial cadastral survey in Palestine under the British mandate. Geographical Journal. 1987 Mar 1:93-8). There are, of course, caveats made, including the need for ready access to airplanes, good weather (perhaps humorlessly, the British Isles are mentioned as not being ideal), and the need for touch-up work with the support of a draftsperson. Perhaps predictably, and as was to be the norm in decades to come, these 
articles elicited conjecture around the accuracy and reliability of the figures relating to cost and time [40]. That said, the notion of using aerial photogrammetric methods in creating large-scale wide-area topographic, and even cadastral, maps was now firmly on the agenda [41].

\section{2. $1920 \mathrm{~s}$}

In the 1920s, recognition continued to increase that beyond military needs, governments should be leading the compilation, and maintenance of, jurisdiction-wide domestic mapping programs, incorporating relevant themes and scales, to support civil governance [42,43]. In the same context, the improving techniques for aerial survey and mapping - and more specific for photogrammetry-were articulated in handbooks and guides [44].

For the case of cadastral maps, the Geographical Journal continued to be a platform of choice for debating the merits of aerial photography applied to mapping. The previously articulated aerial survey approaches, including those estimates of time and cost commitments, would be more thoroughly tested in numerous contexts. Dowson [45], who had acted as Surveyor-General of Egypt, in the previous decade, 1909-19, presented results from that country. Whilst acknowledging the improvements to techniques in that decade, he makes clear that aerial surveys alone cannot replace conventional ground techniques in that context. He cautions against hype: "Great as is the promise of aeroplane photography as an aid to map-making, there is an obvious danger that too much may be expected of this valuable method of filling in map detail" and "So far aeroplane photography has rendered the very great service of enabling a closely accurate record to be instantaneously taken of a considerable block of topographic detail; the accurate assembly of this detail into controlled position in a map is the province of the surveyor, and, so far at least, this requisite control has not been established through the agency of aeroplane photograph". Specifically, on cadastral surveys, he goes on to state: "In sparsely settled, semi-arid areas, where property is held in large units and no great degree of accuracy is required in defining a boundary, it is not usual for the limits of properties to be outlined with sufficient continuity, visibility, and lack of ambiguity for photographic record" and that for more densely occupied urban and rural areas: "the accuracy that is obtainable from aerial photographs is so far of a totally different order to that required for a cadastral survey of a fertile and closely-settled land, and it is in fertile and closely-settled lands that cadastral surveys are principally needed".

Others, such as Bagley [46], reviewing applications to that point, by the French in Morocco, the English in India, and US Government bureaus, arrive at similar conclusions: the developing technique certainly has merit for difficult to access terrain, but is not appropriate for large-scale detailed topographic or cadastral maps. Bergen [47] similarly argues that aerial survey mapping has limited application for cadastral mapping: its best application is still for large-scale contour maps where there is an abundance of ground control-as found in Europe. Its economical application in the Americas, where ground control is often absent, is questioned. Tuttle [48] appears to counter this view, at least in established urban areas, providing details of the application of aerial mapping to support city planning in New York.

Another development in the 1920s was the necessity for cooperation between surveying and mapping disciplines and the emerging and maturing domain of aeronautics. Burchall [49] explores the administrative necessity and relevant costs of linking the disciplines, and later Durward [50] provides a more matured overview of the integrating disciplines. Winterbotham [51], relaying the status-quo in Canada, remarks of the relationship forming between aeronautics and surveying in that jurisdiction, and sees a move beyond hype and despair, towards productive application: "There is everywhere the keenest interest in method and instrument and a marked absence of that sloppy over-confidence or wilful pessimism we have seen sometimes elsewhere in airman and surveyor respectively".

Perhaps confirming this view, and realizing the need for a 'fit-for-purpose' use of aerial surveying in mapping applications, Fiske [52] puts it best: "In approaching the subject 
of the use or aerial photographs the engineer must formulate clearly in his own mind a definite opinion as to what constitutes a map and the purpose it will serve." ... and what would be the good purpose in ... "securing data and trying to incorporate it in a map with any higher degree of accuracy that can or will be employed by the user?". Herein lies an example of the mindset that would later grow into 'fit for purpose land administration' agenda.

\section{Switzerland, Scaling and Spreading (1930 to 1945)}

\section{1. $1930 \mathrm{~s}$}

The 1930s began to reveal, for the first time, scaled whole-of-country implementations of aerial survey for cadastral survey, especially pioneered by Switzerland. Spender [53] (Figure 4), writing in 1932, outlines the extensive use of terrestrial photogrammetry in topographic mapping in Switzerland, and perhaps even more remarkably, the almost exclusive use of aerial surveying for cadastral mapping, having commenced in the mid1920s. Switzerland, having been isolated from the demands of rebuilding post the Great War, and spurred on by scientific demands, matured aerial photographic methods for cadastral surveying. Interestingly, Spender makes it clear that the remarkable speed in uptake-aside from the benefits of swift coverage, addition contextual information, and reduced costs-was a result of private survey firms being primarily responsible for cadastral surveying - and therefore being keen to utilise new technologies, such as stereoplotting machines, and being prepared to take on the risks to maximise economic gains.

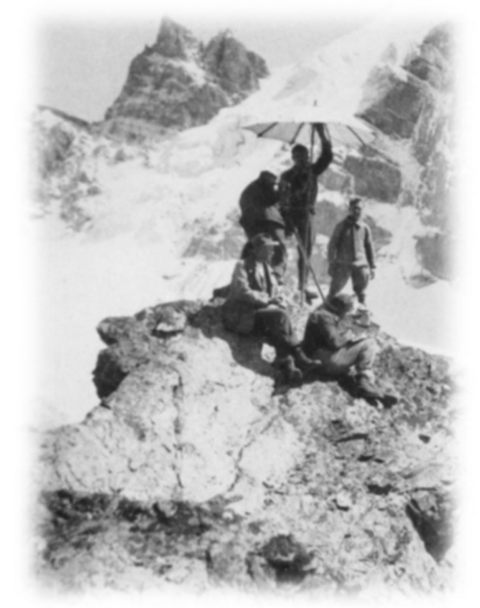

Figure 4. A terrestrial phototheodolite station in Switzerland, although post-1925, cadastral surveys were almost exclusively completed using aerial survey (adapted from [53]).

In terms of the benefits for cost and time: "It is unprofitable to attempt the aerial survey of a district smaller than $20 \mathrm{sq}$. km.; a suitable size to treat as a unit is $100 \mathrm{sq} . \mathrm{km}$. The average total cost of the preparation of cadastral map and topographical "Uebersichtsplan" by these methods, including flying costs but excluding the 4th order triangulation, is 800 Swiss francs per sq. $\mathrm{km}$. This is at least 15 percent cheaper than by the use of terrestrial photogrammetry and up to 30 percent cheaper than a plane-table survey. The cost may be taken as less than 1 percent of the value of the property. If the aeroplane makes photographs of $500 \mathrm{sq} . \mathrm{km}$. in the course of the summer and this figure is exceeded without any difficultly, the flying costs, including the crew, fuel, insurance, and sinking fund, represent 10 percent of the total; the marking of points on the ground 3.75 percent; the photographic work 1.25 percent; and the remaining survey and plotting duties undertaken by the private firm represent 85 percent of the total cost".

In a review by Ripley and others [54], referring to the work of one Colonel Birdseye, the personnel cost between ground and aerial methods is suggested to be equivalent, but the time commitment is cut to one third when using the aerial approach.

Following the lead of Switzerland, other European countries, including Germany, France, Italy (via outsourcing arrangements with the private sector, on the agreement that 
costs would be equivalent or lower to ground survey methods [55]), and Spain followedalthough, despite some use in India [56], Wolff [57] suggests British colonies lagged in the uptake of this method. Salmon [58] countered this view, recalling the earlier British developments from the Great War: "I hope Dr Wolff's interesting article will stimulate to action some of those who have not given sufficient attention to air survey as a method of mapping or planning those areas which lend themselves to that method. At the same time, whether so many of us are as conservative as the author appears to think is a matter for doubt, and moreover we do not all look upon air survey as an "innovation".

That said, it could hardly be argued that those innovations had translated to use in cadastral mapping in British colonies, and rudimentary understandings of photogrammetric principles were still lacking in the surveyor community [59]. Winterbotham [60] lamented the lack of innovation and updating of British maps themselves, seemingly linking the neglect to the ongoing economic depression. The discourse between Wolff and Salmon was part of the emerging professional dialogue on cadastral surveying, occurring in the recently established Empire Survey Review, itself connected to the first Conference of Empire Survey Offices in 1928 [61].

Meanwhile, technological photogrammetric advances and refinements emerging in France, Germany, Italy, and Switzerland were directly contributing to faster-paced cadastral map production [62]. These initiatives relied upon what was later termed 'analogue photogrammetry' (for a more detailed chronology of 'analogue photogrammetry', see: https: //www.asprs.org/wp-content/uploads/pers/1985journal/jul/1985_jul_919-933.pdf, accessed on 18 October 2021), underpinned by earlier-developed stereoscopes, aircraft for aerial surveying, and the methodological refinements of Dr. Carl Pulfrich (later described as the so-called "Father of Stereophotogrammetry"). The United States too was increasingly adopting and using the technological approach, albeit more for topographic applications [54,63]. Similar developments can be observed in Australia [64].

\section{2. $1940 \mathrm{~s}$}

Perhaps predictably, those first scaled applications of photographic methods for land administration appear to have gone into hiatus at the beginning of the 1940s, wholly due to the advent of World War II, at least in terms of reporting. The front-running European nations-Italy, France, and Germany - were either busy with the war effort, or occupied by foreign forces. Those outside Europe, including many colonies of the British Empire, were also equally embroiled in the conflict. This meant that what surveying and mapping capacity was available was almost entirely directed to military mapping. Dick [65], reporting on New Zealand's status in the Empire Survey Review, makes this clear: "... ordinary routine work had further to be reduced to meet the barest needs of the day and the main activity of the staff has consisted of topographic mapping for military purposes".

However, whilst there may have been a growing backlog or hiatus of cadastral mapping, in those contexts where there was no conflict on the ground, geodetic work and national mapping were certainly a focus. This was especially in locations strategic to the war effort, and/or where actual conflict was not a day-to-day impediment to survey work [66-68]. Moreover, the war itself spawned photogrammetry and remote sensing innovations, albeit most likely not being openly reported. This was particularly with regard to the use of aerial and aerospace technologies for surveillance and observation [69]. Therefore, it is of no great surprise that by the end of the conflict in 1945, surveyors were already contemplating the tasks of adequately surveying post-war Europe and beyond [70], and utilizing the innovations developed therein [71,72], including the implications for cadastral maps.

\section{Going Global (1946 to 1969)}

\section{1. $1950 \mathrm{~s}$}

In the later part of the 1940s and into the 1950s, many new case applications would appear from outside Europe: across Africa, Asia, the Middle East, the Americas, and 
Oceania, the maturing techniques were gaining widespread interest and application. The backdrop here was an emergent global perspective on the issues of land tenure security and land reform [73,74]. This marked a move beyond the conventional national-level or colonial mindsets, and the beginnings of a more integrated discourse in land economics, land law, and land surveying/mapping. The development of the United Nations and FAO was key here, and the Land Tenure Centre at the University of Wisconsin [74] was central to the discourse, and the amount of published works begins to increase at this point. What follows cannot be considered complete global coverage of all instances of photogrammetric methods applied to land administration tasks; rather, the aim is to provide insights into the breadth and scale of uptake.

In Africa, Dowson [75], countering his own earlier claims against photogrammetric methods, suggests application in the protectorate of Zanzibar, where an increasing number of unstable agricultural small holdings needed recording in a quick and economical manner (Figure 5). The advancement in techniques and the need for speed most likely informing the change of heart. Smith and Whittaker [76] provide a new commentary and comparison of on-ground methods versus aerial survey techniques, based on work undertaken in Kigezi District in Uganda. Menzies [77], providing a broad historical overview, details the uptake in South Africa, and Adams [78] suggests the use of aerial triangulation techniques to support cadastral mapping in Kenya. For the case of Kenya, it can be noted that rectified photography eventually formed the basis for title plans. Whilst initially intended as temporary records, these were in use well into the 2000s (see Section 8.1). However, the approach was ultimately rejected in other African contexts: it required landowners to plant a specific type of tree along boundary lines, and at least anecdotally speaking, this was found as to be too onerous to achieve at scale. These developments in Africa, during this period, gave rise to debates over the legal implications of the photogrammetric method, at least for jurisdictions where cadastres informed legal ownership. These took the form of discussions around 'pegs versus plans', 'measurements versus monuments', 'fixed boundaries versus general boundaries', and the legal responsibilities (and liabilities) of those undertaking both the ground-based and photogrammetric survey work (see Sections 6.1 and 7.3 and [1], where these debates were later documented).

SUGGESTED METHOD OF ADDING CADASTRAL DETAIL TO PHOTOGRAPHS

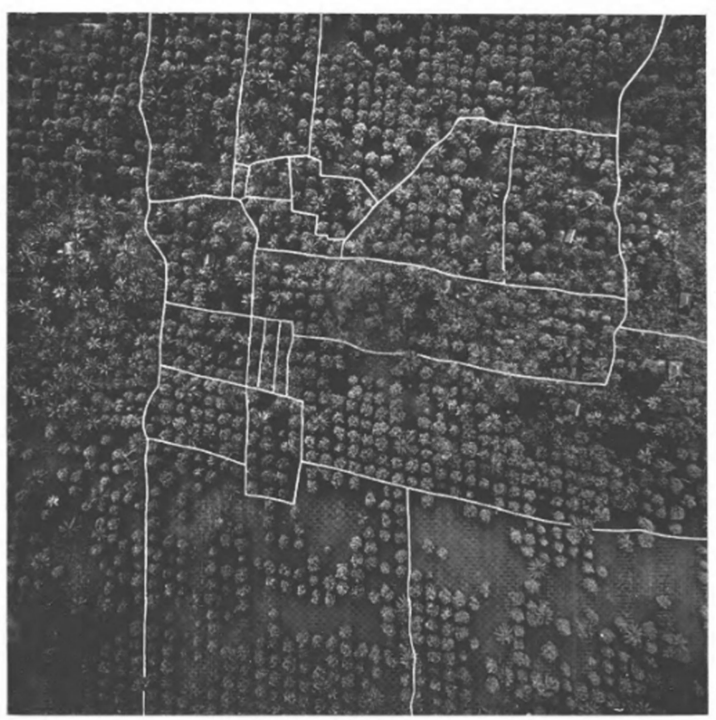

Figure 5. Long before GIS, overlay of cadastral boundaries using photographic techniques was trialled and applied, including in Africa (adapted from [75]).

In the Middle East, Park [79] summarises the effectiveness of the photo mosaic technique to act as a base for resource inventory mapping in the Hashemite Kingdom of Jordan: 
even in the featureless flat landscape, the photographic method is shown to have great utility, including the ability for quick training of Jordanian nationals, and is one-tenth of the cost to produce compared to conventional topographic mapping.

In the Americas, where the application had until this point been limited, Van Zandt [80] provides results of scaled application in Utah in the United States (Figure 6). Other experiments demonstrated positive results in the States of Maryland and Vermont [81] and other areas in the United States [82]. Certainly, as reported by McVay [83], the capacity to cover large areas quickly was increasingly recognised as being suited for mapping public/state land tenures, at least by the responsible government agencies. Andrews [84], called for its use in cadastral surveying in Canada, with Slessor [85] delivering the results from an experimental application of photogrammetric methods versus field methods to map an 'Indian reserve'. From a scientific perspective, the results were considered a great success; however, the obtained accuracies were argued as inadequate for practice. In South America, proponents argued for the application of aerial surveying to support cadastral mapping in Peru [86] and Northeast Brazil [87].

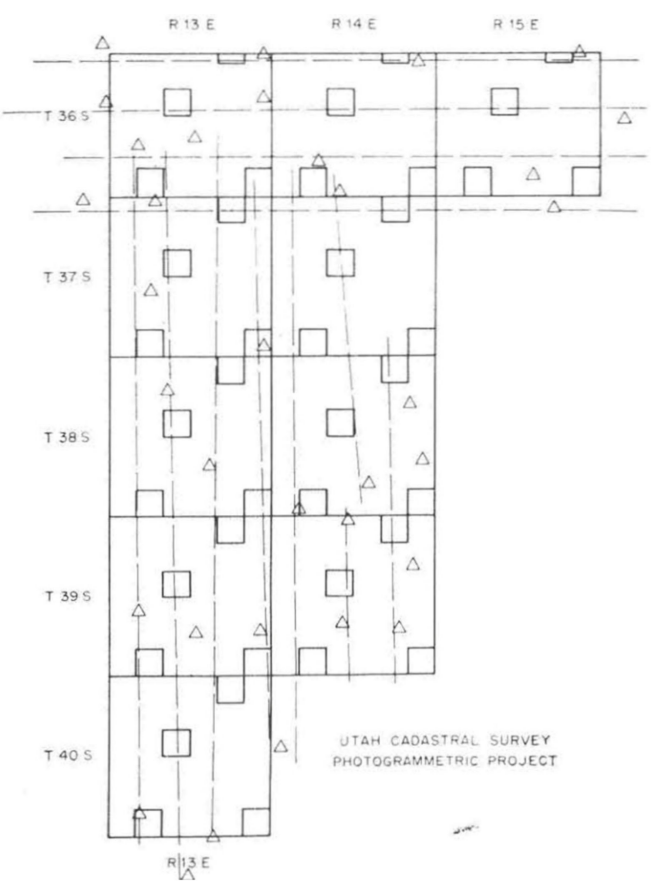

Figure 6. Fusion of photogrammetric and cadastral surveying in Utah, USA: photographic flight lines and control points (adapted from [81]).

In Asia and Oceania, results from applications or experiments in the Philippines [88], Japan [89], and Vietnam [90] (Figure 7)—-the latter case having recently had most of its land records destroyed due to conflict-are reported. In the Philippines, this included an initial pilot of 149,000 hectares, 15 municipalities, and 61,000 lots. Plans for a 15-year program to cover the entire country at the cost of USD 6/Ha were put forward. In Australia, there was certainly growing interest, if not a debate about the relevance of these global developments [91,92]. In the state of NSW, Rasseby [93] reports how whilst not used for parcel mapping directly: "Some significant progress has also been made in the use of photogrammetry to provide control for subdivision of rural land". 


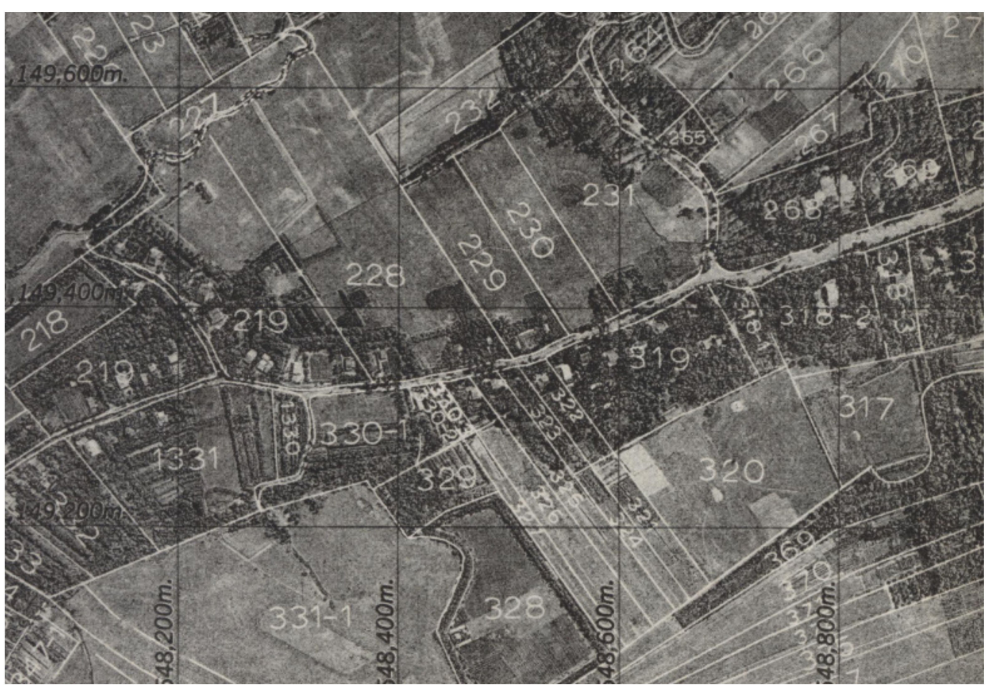

Figure 7. Conflict-strewn Vietnam demonstrated the potential for photogrammetric methods for fast-tracked in parcel mapping to support land reform (Adapted from [90]).

In terms of technical advances, during this period, there was a first move from analogue towards analytical photogrammetry, enabled by the invention of the analytical plotter in 1957 by Uuno (Uki) Vloho Helava: he used a computer to digitally transfer the coordinates between the image and the map (note: Helava later played a central role in the development of the first digital photogrammetric workstation in 1979). Additionally, there were also new technologies emerging: the use of radar, infrared, colour, and other remote-sensor techniques were developing [94]. There were also iterative improvements and refinements to existing techniques and technologies. As was the case in other fieldssuch as soil surveys, forestry, and engineering surveys-in cadastral surveying, these were enabled by the closer collaboration of "surveyors, air navigators, photographers, radar specialists, meteorologists, and instrument designers" [95]. That is, the technical improvements in measurement and plotting accuracy from the war era, were transferred, via professional collaboration, into the domain. The period also provided the first mention of electronic methods and automation, particularly with regard to providing survey control via automatic registration methods [96,97] —although, the same author laments a lack of investment in technical skills to utilise the method more widely. Later in the period, the concept of the 'numerical cadastre' (based around coordinates), enabling the 'multi-purpose cadastre' and 'integrated survey' concepts [98] came to the fore. As outlined by Basye, the first digital land information system was also developed [99]. These innovations were leveraging and combining the outputs of aerial mapping with other survey data, aiming to deliver one integrated map that, amongst other land management goals, as declared by Bonacci [100]: "could serve the title examiner, appraiser, land negotiator, the courts, and many others serving this whole complex of land acquisition".

\section{2. $1960 \mathrm{~s}$}

Moving into the 1960s, applications in land use planning, and broader land managementan emergent and closely related discipline to land registration and cadastral mapping - gained attention [101-104]. A prime example is provided from Norway [105], where an intended 12-year whole-country mapping program sought to use the technique to produce land use classification maps at scales between 1:5000 and 1:100,000. These would later serve as the basis for property boundary determination. This new focus on land use mapping was driven by the utilitarian desire to manage food production, housing, industrialisation, and economic development more efficiently. The pace of post-war development meant that the speed and extra details provided by photographic methods leant well to the context. 
Interestingly, with the planning domain still in its infancy, the relevant works are found in more technical photogrammetric or aeronautic journals.

This period also saw a maturing of land registration and cadastral domains (later to be conceptually merged and known as 'land administration' in 1990) into an aggregated disciplinary body of knowledge. The seminal aggregation [106] and synthesis work of Dowson and Sheppard $[107,108]$ are exemplary here. In the Netherlands, the International Training Centre (ITC) with its dedicated focus skills development in aerial surveying and photogrammetry in developing countries, was established. From early on, the institution considered the specific case of photogrammetry for cadastral surveying [109]. With such developments, aerial surveying and mapping were now truly legitimizing in the field globally. As Hart [110] and Ray [111] both assert, this forced a rethink of what it meant to be a 'surveyor' and how to be trained as one. Certainly, the need for degree programs with a holistic approach to survey and mapping techniques was recognised [112].

That said, the cadastral profession was slow to move in the adoption of photogrammetric methods for cadastral work in many country contexts. Abrams [113] describes how the legal validity of the boundaries produced by photogrammetry is one issue: "One of the problems of this development has been the admissibility of photogrammetrically prepared exhibits into court and other legal proceedings. Demonstrative evidence, particularly in the form of aerial photographs and other photogrammetrically prepared exhibits, has great potential in the field of eminent domain. Research of the relevant case law indicates that admissibility of demonstrative evidence generally has been a question for the discretion of the trial judge in any given litigation".

Irving [114] suggests that it is more to do with the relatively small size of the sector and the lack of competition and drive for innovation: "... it may be that, as we are not among the great spenders of public or private funds, there were more important fields for new methods and the doing of more in less time; still again it may be that equipment manufacturers were enjoying the period of repose with us, and not constantly urging us on with new and bright ideas in bronze and glass".

Thompson [115] is blunter. Referring to the issue of slow adoption by surveyor community, he blames the surveyors themselves: "In the earlier period it was claimed that the photograph could not give the necessary accuracy, and in later period, that even if it could, it was uneconomical. Many results in the 1920s and 1930s were interpreted as showing, both at large and medium scales, that air photograph was not good enough." and ... "it is now clear that the plane-table and chain were being treated as sacred cows, and it was blasphemy to suggest that maps produced by their means might be inaccurate".

At this point, it seems important to make the distinction between the typical work of the government and the private sector with regard to land administration. Typically, it was national or state governments that were concerned with large areas or 'whole of jurisdiction' cadastral coverage, whilst the private (licensed) cadastral surveyor tended to be more orientated towards individual parcels, or small collections thereof. For this reason, given its advantage regarding fast and large-scale coverage, photogrammetric methods tended to be of more interest to government mapping agencies. Most of the students at the abovementioned ITC hailed from these government departments. The method was a 'harder sell' with regard to cost and time benefits for private land surveyors. This was despite the pleas of proponents such as Orvington [116]: “ . . there are many aspects of air survey and photogrammetry which have particular significance for the private surveyor, both for cadastral and topographical surveys and other features of his professional duties".

The divergence in perspectives was important. In many jurisdictions, private agents of the state made up a large proportion of the cadastral surveying professional body. The different foci, business models, and financial interests at play can be seen to have underpinned debates on the merits of ground versus aerial methods, long after the technical and accuracy challenges had been surmounted. 


\section{Space, Cities and Digital Systems (1970 to 1999)}

\subsection{0 s}

Four pervasive and emergent forces came to the fore commencing in the 1970s: space technologies, digital computing, urban planning, and systems thinking. Whilst the geopolitical 'space race' played out in the decade prior, its fruits were exploited by mappers in the following decade. The new terms 'remote sensing' and 'satellite imagery' are observed at this point. Likewise, whilst digital computing developed in the 1960s, it was the 1970s that saw the technology make its first appearance in innovative national mapping and cadastral agencies [117]. Additionally, as rural populations transformed into urban ones in developing contexts, and city centres began de-industrialising in more developed contexts, urban and city planning grew as a domain, and it too needed its maps. The fourth, perhaps less obvious force, cutting through each of the other three, was 'systems thinking'. Its relevance to cadastral studies was made clear by Dale [118], and the theory would impact greatly in developments in subsequent decades.

Regarding space technologies, the benefits of wide-area coverage, at repeated intervals, with multi-spectral coverage, brought about by satellite-based remote sensing, were being recognised across the domains of forestry, soil science, land use planning [119], and the growing area of environmental protection [120]. The characteristics were also identified as being particularly useful for developing contexts [121], where large parts of the landscape suffered from a lack of adequate or up-to-date topographic and natural sources maps. For cadastres, as with earlier photogrammetric approaches, it was public agencies, typically dealing with larger-sized parcels of public lands, that saw the utilisation. Torbet and Woll [122] describe initial applications in the United States linked to public land, deserts, watersheds, and First Nations lands. Lambert [123] explores the potential impacts in Australian surveying and mapping. Kellie [124] appears to undertake a direct appraisal of the emerging techniques on the domain of cadastre; however, unfortunately, only a citation could be found for this work.

Regarding digital computers, leveraging off the convergence of surveying and mapping professions in the previous decades [125], the 1970s saw the convergence of the numerical cadastre concept based upon coordinates from photogrammetric methods [126]), integrated surveys concept, and multi-purpose cadastre concept, into a matured conceptual design, most notably by McLaughlin [127]. The idea of building an integrated and open land information system, incorporating digital imagery as a key dataset, was taking shape $[128,129]$. Key here was the 1979 work of Duane Brown(For more detail on Brown's work see: Brown, J., 2005. "Duane C. Brown Memorial Address", Photogrammetric Engineering and Remote Sensing, 71(6):677-681), whose short-arc method of geodesy helped to prepare the way for the integration of photogrammetry into GIS, via the use of reflective targets.

Regarding urban planning, although numerical and computation photogrammetric approaches had been improving since the 1950s, Braasch [130], noting developments out of Hamburg, Germany, still notes: "The 'graphical cadastre" may be produced by either plane table, or simple photogrammetric methods, but is not recommended" (for cadastral purposes in urban areas) and that: "Photogrammetric methods give excessive errors on short lines, but are gaining favor in their economy, especially in rural areas".

That is, the growing challenge of urban tenure mapping, via photogrammetric methods, was considered a separate challenge to cadastral mapping in other areas [131,132]. Not only did it require higher accuracies (due to higher values), and therefore higher-grade imagery-urban areas generally changed more rapidly, and whilst the time and costs advantages of photogrammetric approaches over time-consuming ground methods were clearly apparent, the embedded approach of using ground methods for urban cadastres continued to curtail the use of imagery [133].

Meanwhile, alongside the abovementioned digital and remote sensing innovations, applications of more traditional photogrammetric methods continued. Weissman [134] provided an update on the contemporary process being used in Switzerland, combin- 
ing photogrammetric measurements with ground methods in cadastral survey creation. Bonnell [135] explains the extensive use of photomapping for legal boundary surveys in the contexts of mining and natural resource management. A fascinating account of the extensive use of photogrammetric techniques, including for creating urban cadastral line maps in Saudi Arabia is also provided [136]. Blachut [137] identifies how, for cadastral purposes, winter photographs are highly useful for boundary determination (at least in more temperate climates). Lafferty [138], echoing the much earlier work of the 1910s-20s, seeks to provide an updated cost-benefit analysis for certain terrain types and differing cadastral accuracy requirements of the use of photogrammetric methods. Dale [139] provides a comprehensive overview of the role of photogrammetric methods in cadastral surveys in Commonwealth countries, finding significant use of the techniques, although limited use in areas with high-value land. Meanwhile, Barrie [140] questions outright the need for ground-based parcel surveys altogether, given the recent advances in computation and photogrammetric methods.

\section{2. $1980 \mathrm{~s}$}

Into the 1980s, space technologies and digital technologies continued to converge, with a growing recognition of the impending impact on land surveying and cadastral mapping [141]. New generations of satellite remote sensing technologies were launched (i.e., Landsat 4; SPOT-1): in the Scandinavian context, including Denmark and Sweden, it was argued that for data capture, traditional aerial photography and geodetic methods were already giving way to spatial data acquired from satellites [142]. However, as pointed out by Lodwick and Paine [143], due to the limitations in resolutions with Landsat 1, 2, and 3; challenges with image registration; and issues with handling the large quantities of data, overall, the surveying profession had lagged behind other fields in the application of remotely sensed imagery.

Linked to these space-driven developments were techniques for integrating remotely sensing data into geographic information systems (GIS) [144]. In the context of cadastres, this took on the specialist form of a land information system (LIS), or equivalents variously incorporating 'multipurpose' and other terms [145], and the sub-domain of land information management emerged [146]. Digital techniques for extracting vector data from imagery and enabling its incorporation into LIS were also developed [147], as were procedures for cadastral map renovation based on similarity transformation [148] and digitisation of data from photogrammetric inputs $[149,150]$. Many countries were at least piloting, for example, in Colombia [151] and Taiwan [152] or were undertaking scaled implementations of these developments [153], as per the case in Canada. This area of cadastral map renovation, upgrading, and updating would be a continued area of focus over subsequent decades, and is more fully unpacked in Bennett et al. [10].

However, it was with conventional photogrammetric methods where most scaled applications continued to occur. Photogrammetric techniques for control network densification were developed $[154,155]$ as were cadastral survey data capture techniques [156]: cost reduction and improved legal certainty were highlighted as key benefits. The application to development projects was also a focus [157], with the World Bank project in Thailand a prominent example [158]. Other experiments also took place, for example, in Zambia $[159,160]$ and Taiwan [153] — but it was still recognised that changeable terrain and tenure systems meant the approach might not be suitable in all locations, for example, in Fiji [161]. The convergence created by the move from analogue photogrammetry in 1960 (e.g., stereo plotters) to analytical/digital ones-in terms of data creation, capture and storage-was again demanding a reappraisal of what constituted a cadastral surveyor [162], of how to offer education and training programs [163,164], of what name to use (e.g., Geomatics [165]), and what research programs should constitute [166]. 


\section{3. $1990 \mathrm{~s}$}

It is tempting to thematically separate the highly digitalised 1990s from the more analogue 1970s and 1980s, given the ubiquity of PCs and scaled uptake of the Internet in that decade; however, ultimately the 1990s capped much of the work of the previous decades. A key development, as explained in Bennett et al. [10], was the internationalisation of the cadastral surveying profession, spurred by the post-Cold War re-establishment of cadastres and land registries in eastern European countries, and the uptake of the unifying term 'land administration'.

In a book of the same name, Dale and McLaughlin [1] provided a synthesis on the debates and options with regard to the use of photogrammetric versus ground-based methods, overall finding that a combination of both is possible. For the specific case of remotely sensed satellite imagery, in agreement with Paulsson and Mundial [167], Dale [168] flags lingering concerns: "In spite of claims that satellite imagery can be used for cadastral surveying, remote sensing is still too crude a set of tools for such a purpose and, like the use of photogrammetric techniques, addresses only part of the cadastral problem. "He rightly affirms that data capture is but one component of the challenge of getting agreement on boundary locations, which is fundamentally a social process, not only technical one.

That said, Jensen [169], revealing an awareness of emerging higher resolution options, is more positive: " . . cadastral (property line) information are best monitored using high spatial resolution panchromatic sensors, including aerial photography (5 0.25 to $1 \mathrm{~m}$ ) and, possibly, the proposed EOSAT Space Imaging IKONOS ( 1 by $1 \mathrm{~m})$, Earthwatch Quickbird pan $(0.8$ by $0.8 \mathrm{~m})$, and Orbview-3 ( 1 by $1 \mathrm{~m}$ ) data." Although it should be noted that he argues that a 0.25 to $0.50 \mathrm{~m}$ spatial resolution is acceptable: this is generally (rightly, or wrongly) outside what cadastral surveying professionals (and associated regulations) would deem acceptable.

Rao et al. $[170,171]$ similarly suggest that the Indian remote sensing satellite program will shortly deliver spatial resolutions aligned with cadastral mapping requirements, particularly in rural areas [172]. Gonzalez [173] predicts the new generations of highresolution satellite imagery could be used for both state-wide and local-level cadastral map production. Jensen [169] also illuminates the issue of invisible boundaries and combined use of ground surveys, ortho photos, and even satellite imagery in the United States: "In many instances, the fence lines are the cadastral property lines. If the fence lines are not visible or are not truly on the property line, the property lines are located by a surveyor and the information is overlaid onto an orthophotograph or planimetric map database to represent the legal cadastral (property) map. Many municipalities in the United States use high spatial resolution imagery such as this as the source for some of the cadastral information and or as an image back-drop upon which surveyed cadastral and tax information are portrayed".

Meanwhile, Schmitt et al. [174] show the application of available high-resolution satellite imagery in identifying settlement structures and changes therein. Leberl et al. [175], commentating on the relevance of remote sensing technologies to the Austrian context, outline the need-if uptake and use are to increase-for the tailoring of imagery products to suit those local and district users who are not looking for nationwide coverage. Moreover, they also make clear the great benefit of repeated capture enabled by satellites, something that is not a given with traditional aerial photogrammetry.

On digital computing, the transition to digital ortho-photo production and use occurred in the 1990s [176], enabling the fusion of GIS/LIS and digital imagery sources [177]. Konecny [178] provides many more scaled examples from German and World Bank donor projects, including Albania (USD 5/parcel) (as do Leke et al. [179]), Georgia, Cambodia, Ethiopia, Argentina, Peru, and Honduras. Holstein [180] adds Brazil to a similar list, but also explains that whilst the use of imagery has its advantages, these techniques require up to an 18-month lead time in terms of flight preparation and base imagery production. For this reason, more flexible methods, including an increased exploration of softcopy digital imagery, were underway. However, here, despite the clear benefits of going digital, issues around poor underlying technology infrastructure and limited capacity were already recognised [181]. Anderson [182] proposes the approach in Mozambique, in alignment 
with new land laws, and Christensen et al. [183] in Namibia. With regard to the issue of urban cadastral data, Al-garni [184] demonstrated the application using aerial photographs in Riyadh. Harcombe and Williamson [185] show the novel use for low-value lands in the western parts of New South Wales in Australia, making use of helicopter surveys for geodetic control.

New applications of other imagery-based technologies also arrived in the 1990s, for example, historical land record archive scanning, as suggested by Boatta [186]. Mohamed et al. [187] propose the novel use for the identification and demarcation of, until then, unrecorded indigenous lands. Ehlers [188] reveals an imagery-based approach for informal settlement identification and management-including informal land tenure parcel identification. Fourie [181] also highlights the need for systems build around visualisation (i.e., imagery) for these contexts. Onsrud [189], also on informal or unrecorded land tenures, almost harking back to the first terrestrial photographic methods in the late 1800s, but also foreshadowing the pro-poor approaches to come, suggests the incorporation of photos into an integrated data gathering approach, for use by locals within an unmapped community. Similarly, Mason and Fraser [190] look at the issue of informal settlement mapping and propose the use of "high-resolution satellite imaging, small format digital aerial imagery and digital multispectral video systems" and "also discuss the example of automated shack extraction from aerial imagery."

Bartle et al. [191], with a similar mindset, propose an automated approach for matching field boundaries in Landsat imagery with cadastral boundaries. This appears to be one of the earliest works on cadastral boundary feature extraction: a topic that would garner much interest in the subsequent decades. However, as would be experienced later, Pinz et al. [192] predict active fusion of remotely sensed data and cadastral boundaries would be highly challenging compared to other thematic layers. This is not even to mention, as explained by Okpala [193], how current laws and regulations continued to impede or disallow the use of imagery-based techniques for the generation of crucial nationwide land parcel maps for land management purposes.

\section{Deluge of Digital, Drones, Dimensions and Data (2000 to 2021)}

\subsection{0 s and 2010s}

In the 2000s, a plethora of technological developments created strong momentum for uptake of remote sensing methods in land administration: digital photogrammetry, high-resolution satellite imagery (HRSI); unmanned aerial vehicles (UAVs); lidar; SAR radar; oblique photogrammetry; and pictometry all emerged, or matured, as alternate technological approaches that could support endeavours. This included not only conventional 2D cadastral mapping, but also the move towards new land administration applications, namely 3D cadastres, marine cadastres, and previously unknown or unmapped property rights, restrictions, and responsibilities such as cable networks, biota/carbon rights, and solar rights. Moreover, convergence with the broader establishment of a high-speed Internet infrastructure, cloud-based computer processing, web mapping services, smart mobile devices, and artificial intelligence enabled new ways of creating and sharing imagery-based land administration information.

It needs to be noted that during this period, the quantity of published scientific literature increased significantly across many disciplines, including land administration. The reasons for this are not the focus here, and are briefly unpacked in Bennett et al. [5]. However, in the context of this historical review, unlike the other periods covered thus far, this increase makes it challenging to incorporate all contributions whilst also maintaining the structure of the paper. Opportunely, the increase in scientific contributions also drove the compilation of meta-studies, for example [194-196] (this included detailed historic reviews on photogrammetric technologies. For example, see the 2010 work of Hobbie: https: / / www.isprs.org/society/history /Hobbie-The-development-ofphotogrammetric-instruments-and-methods-at-Carl-Zeiss-in-Oberkochen.pdf, accessed 
on 18 October 2021), and therefore, in this review, where appropriate, we direct readers to those more detailed reviews of specific topics.

Regarding HRSI, improvements in spatial resolution (i.e., pixel size $<50 \mathrm{~cm}$ ), making it comparable with aerial orthophotos, helped to curb concerns over property boundary identification and delimitation, particularly for rural lands. Whilst the potential was first recognised in the 1990s [197], a wave of experimentation, piloting, and even scaled use was observed globally in the 2000s. Sahin et al. [198] provide an early, although incomplete analysis of Ikonos imagery for cadastres in Turkey. Likewise, Fraser [199] demonstrated the utility and potential in Bhutan. In nearby Pakistan, Ali et al. $[200,201]$ find that costs and time for cadastral mapping, combined with GNSS positioning, could be cut in half. In India, continuing their work from the 1990s, Rao et al. [202] demonstrate how HRSI is applicable for cadastral boundary determination in India, as do Sapra et al. [203], for the case of headsup digitisation of HRSI for forested lands. Sengupta et al. [204], in a novel experiment, demonstrate the fusion of HRSI (GeoEye) with older colonial-era parcel maps for cadastral updating purposes. In neighbouring Nepal, Panday [205] successfully trials the use of HRSI preloaded into mobile devices for remote community boundary definitions. Further south, Andri et al. [206] suggest HRSI application for participatory tenure mapping in Indonesia. In Africa, Asiama et al. [207] present positive results from participatory mapping activities in rural Ghana, also with HRSI preloaded into mobile devices. Balas et al. [208] show similar application potential in Mozambique, and importantly, regulations were friendly towards its use. Ondulu et al. [209] consider the use of HRSI an ideal application for undertaking long-overdue updates to what were originally intended as temporary parcel index maps created in Kenya, 50 years earlier (See Section 6.1 for a description of this earlier work). Lengoiboni et al. [210] suggest the approach could be extended for recording the dynamic land tenures of Kenya's nomadic pastoralists. In Iraq, Hassan et al. [211] provide an accuracy assessment for the improvement of historical graphical cadastral maps in Kurkuk City, Iraq. In another post-conflict situation, Jones et al. [212] show the potential in Colombia. HRSI was clearly now proven, if not ubiquitous, in land administration, certainly in terms of R\&D, but unfortunately, laws and regulations did not always enable easy or scaled application.

Alongside HRSI, much focus was also afforded to the possibilities brought about by digital camera technology, including automatic orientation, dense image matching, and automated data processing. In terms of image acquisition, film-based cameras were replaced by a variety of active and passive sensors, and a combination of those, mounted on different platforms [213]. These were increasingly integrated with onboard GNSS receivers and inertial measurement units (IMU) [214]. With the significant increase in image quality and quantities of data, attention turned to algorithm development for sensor modelling [215]. Automatic image orientation also gained significant attention, being inspired by the computer vision algorithms such as structure from motion (SfM) and from robotics, simultaneous localisation and mapping (SLAM), new methods were developed, including scale-invariant feature transform (SIFT) [216], and speed up robust feature transformation (SURF) [217]. For detecting blunders, the random sample consensus (RANSAC) [218] algorithm was created. Another focus and advance were thematic information extraction [219]. In this respect, classifications such as support vector machine (SVM) [220] and random forest (RF) [221] have been applied actively. In addition, new change detection techniques were developed [222]. The above-mentioned developments in photogrammetry have been applied in numerous countries. To achieve a digital cadastral database in support of LIS in India, tests for Andhra Pradesh districts, across over 10,000 sq.km were performed in 2011 [223]. Another example is the work on land parcel boundary delineation based on aerial survey in Azerbaijan [224]. In addition, digital aerial images taken over Ghana in 2014 were analysed by Offei et al. [225], aiming to assess the compliance with residential building standards in the context of the local customary land tenure system. Other examples of assessment of digital aerial photogrammetry with small or large format cameras for cadastral applications were tested in Nepal [226], Indonesia [227], Costa Rica [228], 
Jordan [229], Turkey [230]. A framework for the automatic characterisation of real property based on aerial photography was proposed by Austrian researchers in [231]. In addition, an interesting exploration estimating the positional accuracy of a parcel boundary dataset based on unrectified aerial images has been done by Siriba in [232].

Regarding UAVs, developments here countered arguments that the one-time collection of imagery was costly and too quickly became outdated: UAVs could, in a cost-effective and as-needed manner, quickly capture a small number of parcels at high accuracy and provide more contextual information than an equivalent ground-based survey. Mumbone [233] trials the application in rural Namibia, in the context of mapping communal villages, for which aerial imagery was explored years earlier [234]. These communities are often separated by large distances making regular aerial photography prohibitive. Ramadhani et al. [235] and Yuwono et al. [236] assess and determine high relevance for the approach in both rural and urban Indonesia, and later Aditya [237] undertakes a larger scaled pilot in the context of participatory tenure mapping. Kurczynski et al. [238] and Cienciala [239] both reveal the potential for UAVs for sporadic cadastral updating in Poland. Other arguments are made for Kenya [240], and trials are undertaken [241] here and in Rwanda [242]. Stocker et al. [243] reveal how for the case of Rwanda, the three different UAV methods could align with administrative requirements, notwithstanding the limits relating to law and capacity. In the same context, Flores et al. [244] consider the governance challenges of UAV introduction. In a related application, Ali [245] demonstrates the potential for land valuation in Zimbabwe. Other investigations include the comparative work of Karatas in Turkey [246], against classical methods, Koeva et al.'s comparative work in Rwanda [247], Mbarga's [248] assessment for application in Cameroon, and perhaps most influentially, Stocker et al.'s [249] recognition that, again, it is regulatory issues-for both UAV usage generally, and specifically for cadastral surveys-that may determine the ultimate update of the technology.

Lidar techniques, both terrestrial and aerial, provided a new means for creating cadastral information. Point cloud data are inherently 3D, and this creates the opportunity to support the growing demand for 3D cadastres, 'indoor' data capture, and marine/littoral zone tenure mapping. Until now, these needs were not well supported by conventional groundsurvey methods nor conventional photogrammetric ones. An overview of the main developments on 3D cadastres, including applications of lidar, is provided by Stoter et al. [250], with updates in Van Oosterom et al. [251].

Specifically, on lidar applications outdoors, in an early work, Filin et al. [252] identify methods for fusing lidar point cloud data with cadastral maps. A significant challenge would be creating efficient workflows for extracting simple vector boundaries: automated feature recognition would become a focus not only for lidar data, but also other large, remotely sensed datasets. Whist these automation techniques are covered in more detail below, Kodors et al. [253] and Kumar et al. [254] provide an early method for building and real-estate capture. Meanwhile, others undertook country-specific explorations: Giannaka et al. [255] explore the potential in Greece; Drobez et al. [256] more generally in Slovenia; Luo et al. [257] develop a workflow for Vanuatu (Figure 8); Wierzbicki et al. [258] fuse lidar and orthophoto techniques for cadastral modernisation in Poland; and Griffith Charles et al. [259] trial the approach in low-value informal lands in Trinidad and Tobago. On the latter, the low-cost specifications, whilst not ideal, could support the preparation of spatial data in the context of 3D cadastres. Lubeck [260], in related developments, uses SAR-radar and its application in fence detection to support ground methods in Brazil. Going underground and indoor with lidar, Rajabifard et al. [261] provide full coverage on BIM developments relating to land administration, and provide full coverage for BIM data capture options, including lidar techniques. Koeva et al. [262] provide a novel indoor cadastral data capture solution based on terrestrial scanning. Beida et al. [263] demonstrate the use case for capturing underground 3D objects and converting them into cadastral objects. Yan et al. [264] supplement similar methods with ground-penetrating radar (GPR) to support cadastral object capture. Other novel data capture technologies emerging in 
this era and applied to land administration, at least conceptually and/or experimentally, included oblique aerial imagery and pictometry (the process of capturing and stitching building façade oblique imagery together), as demonstrated in Kisa et al. [265] and Lemmens et al. [266], respectively.

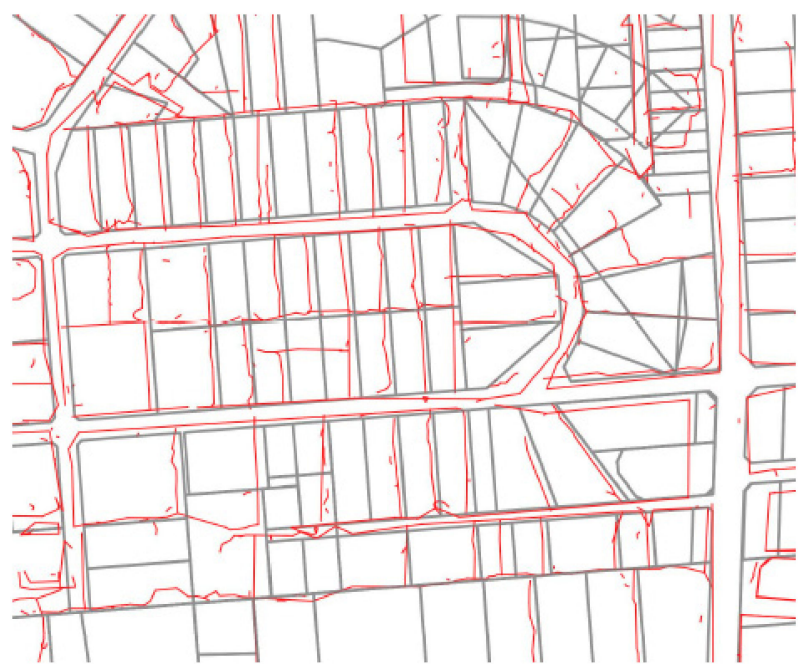

Figure 8. The 2000s saw convergence in data capture technologies and integrated workflows for map production, as demonstrated by [257], where lidar data, aerial imagery, and open-source software were used to generate a parcel layer (red lines) with limited human input. Note: grey lines are the original cadastral boundaries, used for comparison.

Here, linked to Luo et al. [257] above, it is worth mentioning Luo et al. [267]. Using existing cadastral maps as baseline data, they quantify the overlap between legal/cadastral boundaries and visible features. This is important: remote sensing and photogrammetric methods are premised on the idea that physical boundaries overlap with legal boundaries. The results here tend to confirm the anecdotal notion that $70 \%$ of cadastral boundaries were indeed visible or physical, at least in the context studied.

Additionally, during this period, computer processing speeds, networking speeds, and storage capacity exponentially increased. As mentioned above, this reduced image processing times, mosaic creation, and so on, although the amount of imagery data being captured and the density of pixels within these images also exponentially increased. Geocloud platforms combining multiple sources of image data needed for land tenure recording have been developed [268]. The first era of land information systems began to give way to second generation systems, relying on web services for transaction and data delivery [269]. The concept of SDIs fully matured, and alongside cadastral data layers [270], high-resolution georeferenced imagery was often considered a fundamental layer or part of a broader land administration data warehouse [271]: the division between imagery data and land administration data was increasingly blurred. These developments promoted standardisation in the domain, with ISO 19152 Land Administration Domain Model (LADM) [272], a data model standard, being endorsed in 2012. The cadastral and survey data packages within the model were generalisable enough to handle the incorporation of imagery-derived cadastral data and imagery itself as source data.

The final major technological advance in the era was the resurgence of artificial intelligence (AI) and machine learning techniques. For land administration, these offered the opportunity to automate processes for identifying, vectorizing, and validating cadastral boundaries. On this, Commelinck et al. [273] provide a review of these developments up to 2016, albeit primarily focused on UAV imagery. More recently, Bennett et al. [5] provide a review of AI techniques applied to the specific case of land administration maintenance. In Crommelinck et al.'s [273] generalised workflow consisting of preprocessing, image segmentation, line extraction, contour generation and post-processing, an open-source solution 
is developed. Due to the difficulties in training algorithms, semi-automated methods tend to be more promising [274]. Whilst Masouleh [275] focusses on 3D cadastres, proposing a deep learning methodology to support the reconstruction of buildings from aerial images, most of the work at this point focuses on 2D applications. Indeed, the techniques are seen to offer much hope in developing contexts where the greater majority of land parcels might not be mapped, or at least are very outdated [276]. Wassie et al. [277] (Figure 9) develop an approach using HRSI for rural Ethiopia, finding that regular smallholder parcels lend themselves well to the technique.

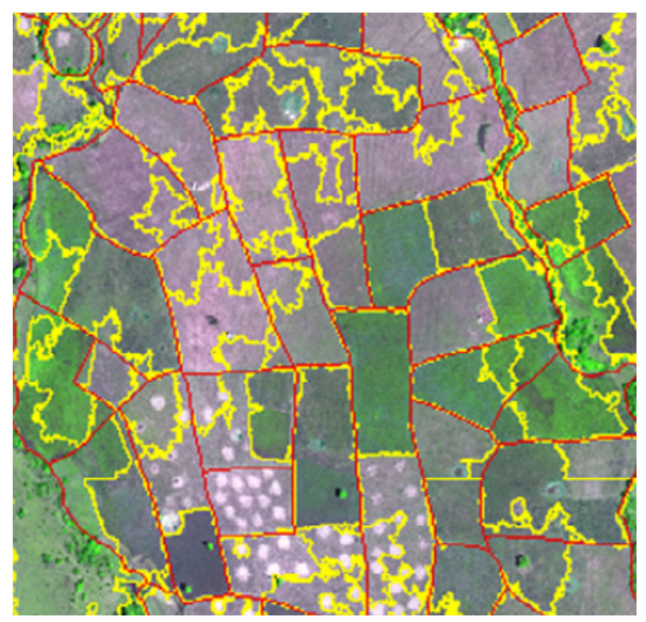

Figure 9. Wassie et al. [277] used open-source software to develop a workflow to extract smallholder parcel boundaries using HRSI in Ethiopia. Note: red = control boundaries; yellow = extracted.

Koeva et al. [278] show how such methods could be integrated with other innovations, including cloud services, UAV usage, and sketch mapping. Meanwhile, Fetai et al. [279] develop an approach using UAV imagery and off-the-shelf feature extraction tools, also with promising results. Park and Song [280] develop an approach for detecting cadastral parcel changes, also using hyperspectral UAV imagery. A key requirement for any AI technique is that the total cost and time for delivering the final boundaries, including preand post-processing and editing, should not be higher than the cost of non-automated techniques. This remains a challenge: even if $60-70 \%$ of boundaries can be extracted, the editing work involved still often takes the total cost over that of manual methods. For the case of land administration, unlike other thematic geospatial layers, it is generally an expectation to have $100 \%$ accuracy (or very close to it). Therefore, comparative work, between manual and automated methods, undertaken by Nyandwai et al. [281] (Figure 10), continues to be important: current rates are too low to be brought into production in many contexts, but could act as a 'first cut' cadastre in some contexts. Most recently, Xia et al. [282] used a convolutional neural network to improve extraction quality further (Figure 11).

Perhaps most promisingly in this era was the fact that the digital advances from previous decades became affordable and accessible in most contexts globally: mobile communications, smart devices, and high-speed Internet were not only the domain of developed contexts. Moreover, high-resolution satellite imagery covered the majority of the Earth's surface. This motivated the concepts of crowdsourced cadastres, participatory land administration, pro-poor land recordation [283], and more broadly, fit for purpose land administration (FFPLA) [284], all of which, learning from the lessons of development projects in the previous decades, and ongoing ones in the early 2000s, such as Cambodia [285], heavily advocated for the use of remotely sensed imagery, in all forms, to support data capture, and as Bennett et al. [5] explain, were ultimately endorsed in the Framework for Effective Land Administration (FELA) of the United Nations Committee of Experts on Global Geospatial Information Management. As always, this was understood to include ground visits, for sensitisation, demarcation, or validation, especially in the initial 
registration projects [286]: imagery alone was not enough [287]. Whilst many in the land sector argued that FFPLA, and associated terms, were nothing new (indeed, as shown in the preceding sections, imagery-intensive methods in land administration projects dated back decades), the branding was used to frame and propel experimentation with new technologies, pilots, and scaled work. Regarding the latter, the Rwandan case of mapping $+10 \mathrm{M}$ parcels, with imagery, over a 3-5-year period was oft-cited [284]. Other explorations, including participatory methods and/or imagery-based approaches, were undertaken in Greece [288], Namibia, Ghana, and Kenya, as described in Chigbu et al. [289] and Koeva et al. [290]. The South African context is also demonstrated by Williams-Wynn [291] as being ready for FFPLA, based upon imagery, and that the legislative basis is already supportive. Zein et al. [292] provided an updated comparison of imagery sources-HRSI, UAVs and digital orthophoto techniques-in the context of FFPLA. They find that a cost of USD 7/parcel is achievable and that the selection of the most appropriate source will depend on the context. Simplifying things even further, the point cadastre concept was revisited [293], where a single point (rather than complex to capture polygons), overlaid on high-resolution imagery, could be used to identify rights.

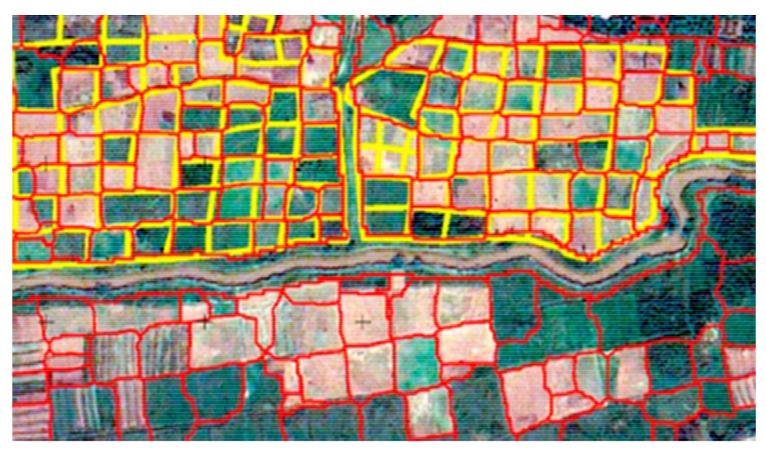

Figure 10. Nyandwai et al.'s method [281] created a 'first cut' cadastre (yellow) that could be taken to the field for validation.

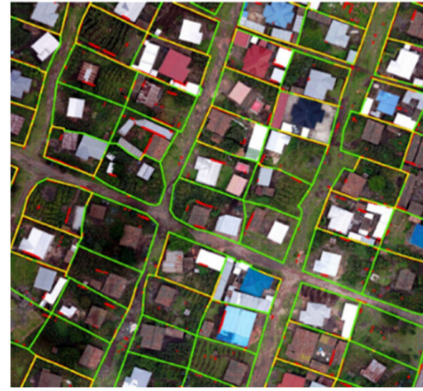

(a)

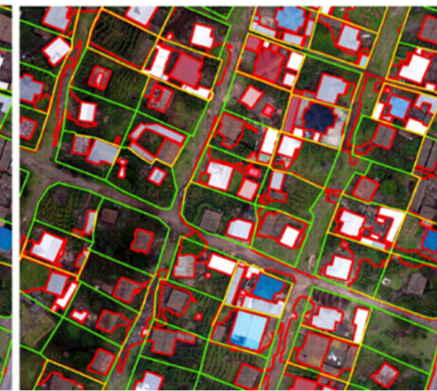

(b)

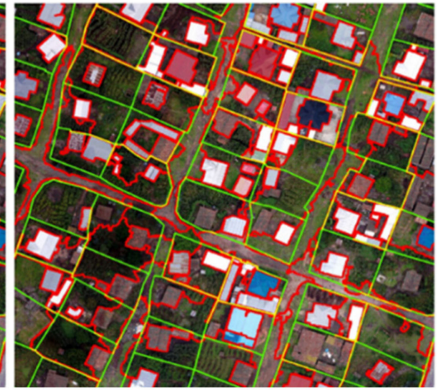

(c)

Figure 11. Xue et al. [282] compared three emerging feature extraction approaches for parcel boundaries: (a) fully convolutional networks (FCNs); (b) globalised probability of boundary ( $\mathrm{gPb}$ ); (c) multi-resolution segmentation (MRS). Note: Yellow lines are 'true positive'; red lines are 'false positive'; and green lines are 'false negative.'.

Meanwhile, beyond all the innovations around digital photogrammetry, HRSI, UAVs, AI, lidar and FFPLA, work continued, on the many decades long, surveyor-realisation that photogrammetric methods could and ought to be used to support formal and conventional cadastral surveying tasks. Here, use cases including hilly areas in Nepal [226], forest land in Greece [294], cadastral updating and illegal building detection in Turkey [230,295], urban mapping based on satellite data in Bulgaria [296], digital aerial photogrammetric building footprint additions to cadastres in Poland [297], and the use of historic imagery in the Slovak Republic for updating [298] are observed. 


\section{Discussion}

This section does not seek to revisit the minutia in the developments, debates and discourse outlined above. Instead, it focuses on: (i) providing a concise synthesis of the key periods, drives, developments, and cases from the review; (ii) confirming the overarching hypothesis that photogrammetric and remote sensing methods have a strong historical and contemporary presence in land administration practice; (iii) providing a conclusive statement on the various cost-benefit analyses covered in this review; (iv) showing the limitations, at least in the contemporary era, in framing data capture methods in land administration as a dichotomous issue; (v) providing an important reminder of the issue of 'invisible boundaries' in the context of remote sensing techniques; (vi) highlighting legal and regulatory constraints; (vii) making mention of the need to consider the broader land management domain (versus land administration); and (viii) briefly casting forward to hypothesise emerging approaches.

First, the major findings from the review are presented both thematically (Figure 12) and geographically (Figure 13). For the thematic depiction, these are organised by the chronological periods identified in the review process. In addition, the key drivers, technological developments and illustrative cases are also depicted.

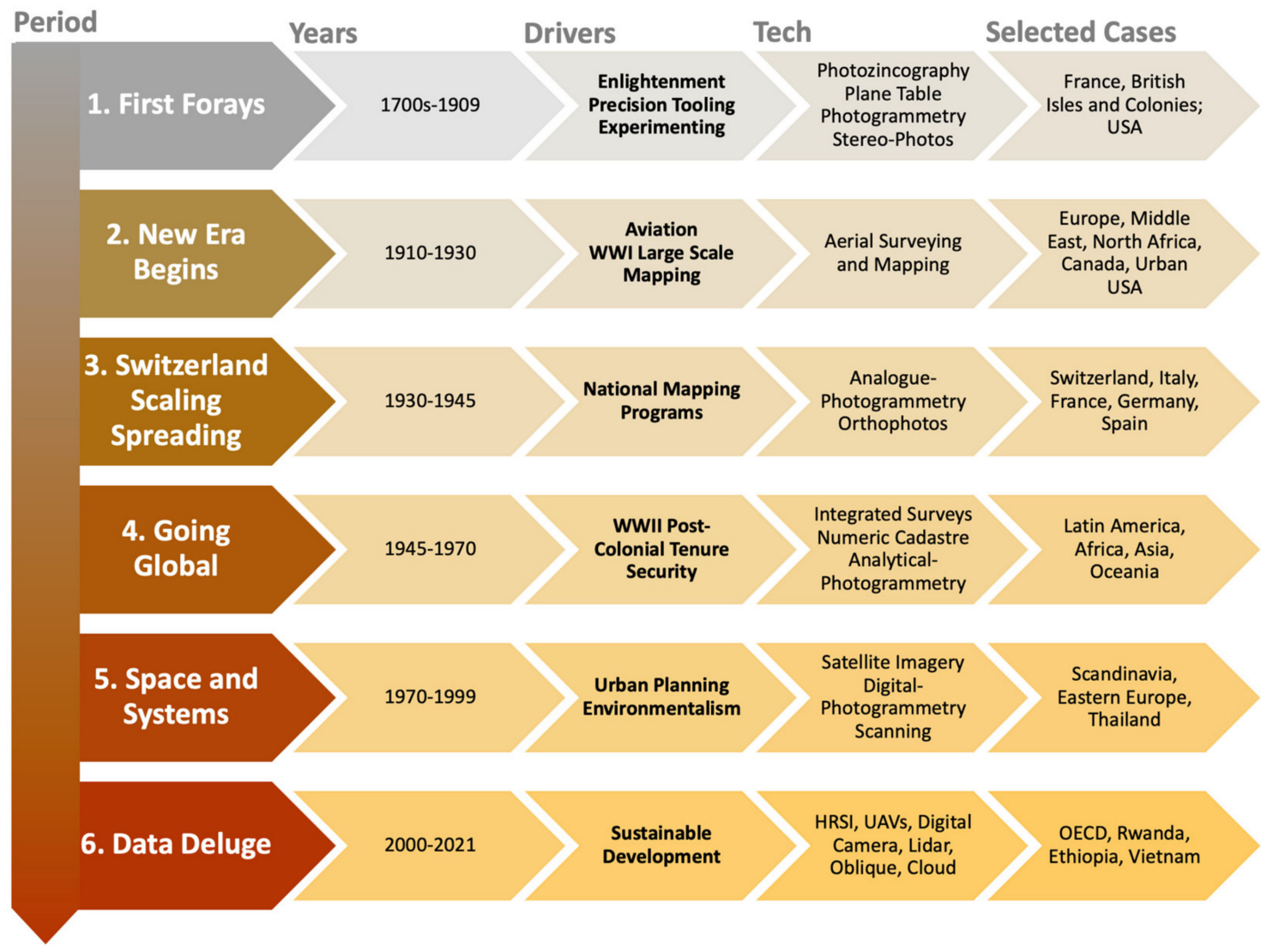

Figure 12. Origins and developments of photogrammetry and remote sensing applied in land administration.

Second, the overarching message is clear enough in the evidence. That is, almost one hundred years after European countries demonstrated the ability to use photogrammetric methods to produce high-quality and comprehensive cadastral coverage-with far more rudimentary technologies than have since developed-any remnant arguments on the use, and apparent limitations, of photogrammetric methods and remote sensing applied to land administration can hardly be sustained. This is not to say that ground methods have become redundant; on the contrary, ground methods continue to dominate in many jurisdictions. Whether this is to do with regulatory inertia, sector self-interest, or driven by considered cost-benefit analyses can be debated, but really ought not to be. What is more certain is 
that the surveying community, regardless of the jurisdiction in which they operate, owe it to its citizenry to ascertain how best to incorporate imagery-driven cadastral mapping approaches, at least in conjunction with ground-based methods, into land administration functions. Arguments around cost, time, and accuracy for capture would appear very hard to sustain; and cloud computing and high-speed internet overcome the issue of transferring and processing large amounts of remotely sensed data between stakeholders.

Published Case Examples 1900 to 2021

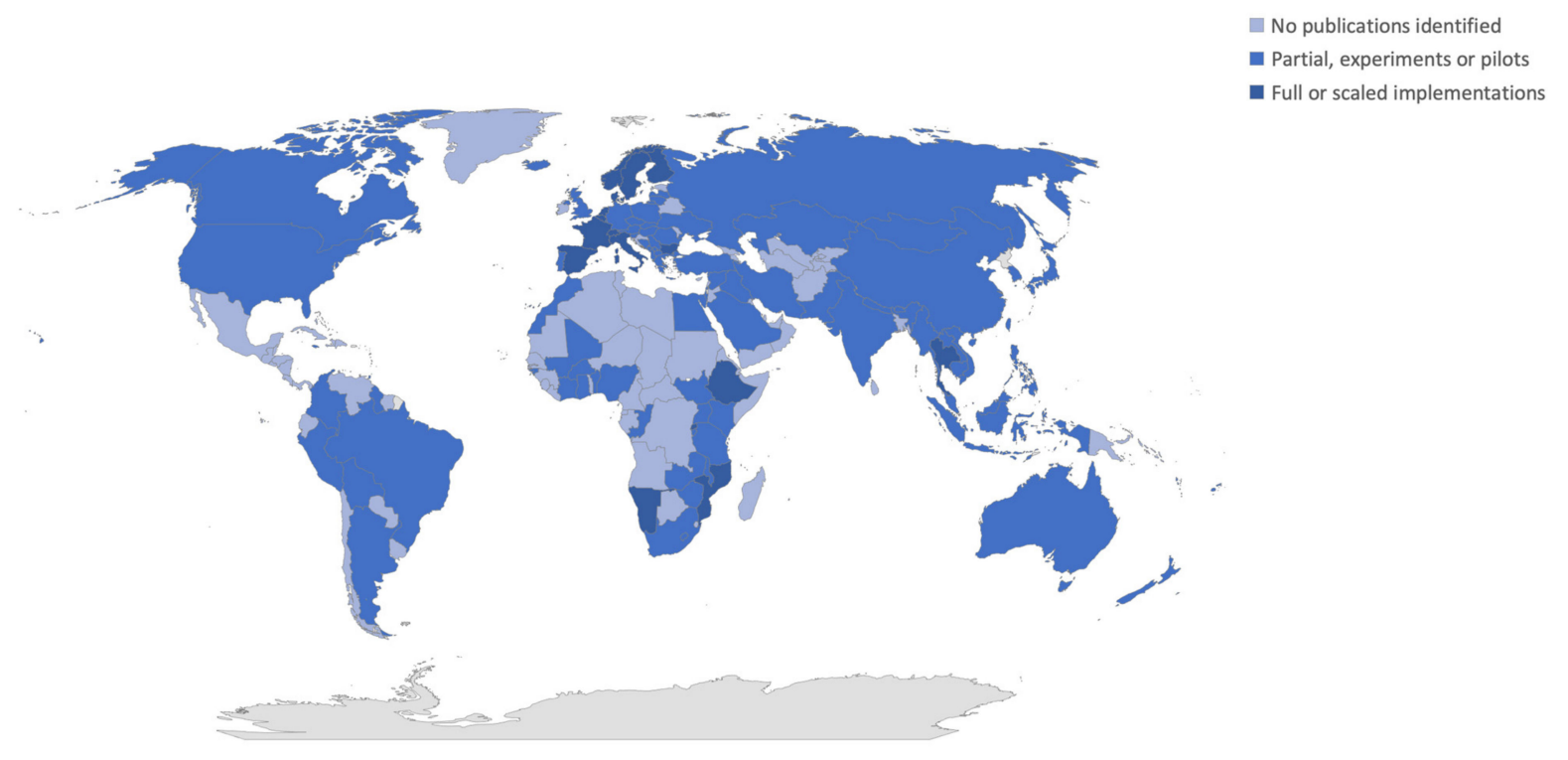

Figure 13. Remote sensing and photogrammetry applied to land administration: review results depicted geographically.

Third, this review did not provide a conclusive endpoint or structured comparison of the cost-benefit studies completed, as they emerged over the decades, with regard to photogrammetric methods (including remote sensing) and ground-based methods. In general, most of these studies sought to demonstrate the efficiencies that could be gained by aerial or image-based methods, at a particular point in time. If these were countered, it was usually with regard to what costs were not being included or excluded in the analyses. Here, the authors agree that cost-benefit analyses can be open to bias or manipulation, and without the means to test the claims in several papers, we simply presented the claims and rebuttals of both sides. That said, through the significant body of works provided, counter claims that imagery-based methods are not suitable in land administration tended to be accompanied with less empirical work.

Fourth, the more recent eras demonstrate that convergence of ground-methods and photogrammetric/remote-sensing methods is increasingly the norm: in practice, thanks to digitalisation, the dichotomy between ground and air is harder to ascertain-that is, the tools, the techniques, the resulting data and maps, and the underlying training programs are increasingly intertwined.

Fifth, noting the positive developments above, it is important to always keep in mind the issue of 'invisible boundaries' - that is, those boundaries that exist purely as social (and potentially legal) concepts in the minds of parties, and do not have a physical presence. Surprisingly, this issue was only explored more empirically in the final era; however, for imagery-based approaches, it is key issue in terms of achieving completeness and coverage, where such approaches are said to be superior. Whilst many cadastral boundaries have a physical presence, being able to be sensed remotely, many do not [299], and as shown by Luo et al. [267], whilst up to $70 \%$ could be sensed, other studies show [300,301] that in some contexts, physical boundaries may be absent altogether. That said, this still does not negate the use of imagery in those contexts: imagery, by its nature, provides contextual information that can be extremely supportive of land tenure, land value, and land use 
planning activities. Moreover, land administration as a domain has long recognised the different manifestations, perspectives, or representations that cadastral boundaries have, variously including combinations of physical natural features, person-made features (stakes or monuments), legal authority, social recognition, textual descriptions (metes and bounds), graphical depictions (be they scaled accurately scale, or not), numerical or coordinated descriptions, and more recently, digital representations. No technological approach can cover all of these aspects; however, remote sensing and photogrammetry can certainly support in some of them.

Sixth, mainly due to the historic nature of the land administration profession being more technology-oriented, the works reviewed here tended to have an overtly technological bias, with an overt focus on the spatial accuracy debate. For example, many works focused on 'how to' apply technologies-or, as in other examples, the cost-benefit analyses tended to focus on the costs for data capture, rather than taking a broader view on legal implications, staff retraining costs, awareness raising in beneficiary communities, or governance costs. However, these 'other' issues are most likely where the major blockers for the uptake of remote sensing technologies in land administration occur. In particular, laws and regulations around what tools and techniques can be used to create cadastral surveys, the legal responsibilities or mandate (e.g., licences) of those completing the surveying (whether ground-based or photogrammetric), or even the more philosophical debate on what can or should constitute a cadastral boundary (see [302] and [303], for example), are of considerable importance, but, apart from the work of Stocker et al. [249], far fewer dedicated works on these issues, directly relating to remote sensing and land photogrammetric methods, were found in the review.

Seventh, it needs to be recognised that this review focused on 'land administration': the broader area of land management cannot be said to have been fully covered. Most definitions of land administration, and certainly land management, would incorporate land tenure, land value, land use planning, and land development. Although these other functions are certainly covered variously in this review, primarily, the review here systematically concentrated on land tenure, linked to registration and cadastres. This limitation was somewhat intentional, given that the scope of work would have been too large. Nonetheless, it is noted, and moreover, it is suggested that the literature from these related areas would reveal a similar trajectory in terms of imagery-based technologies and techniques with regard to application, although this cannot be said for sure. Likewise, the limitation of focusing only on English literature is again noted. Where deemed necessary, it is encouraged for others to undertake similar studies of French, German and Spanish works-noting that many of the English works cited in this work refer directly to developments from contexts using those languages.

Eighth, looking ahead, whilst past developments cannot necessarily be used to predict future progress, it appears quite certain that emerging remote sensing technologies will continue to be experimented on within land administration. The period for scaled diffusion and uptake of those innovations, however, may be more rapid than in the past. The era of digital transformation makes it harder to sustain legal and institutional barriers to change: starts-ups and alternate land administration service providers can now more easily enter the market. In terms of immediate developments, AI and feature extraction techniques will continue to garner attention and will likely be fused with other data sources, both statutory and non-statutory, and social and environmental, to create more intelligent land boundary recognition algorithms. Regardless of this automation, it seems likely that human mediation will remain in some form for the foreseeable future. Integration of the use cases of land use planning, land valuation, land development, marine environment, underground, indoor and 3D, more generally, will continue to drive developments in practice and training courses. 


\section{Conclusions}

This paper began from the premise that, at least conventionally in many countries (although, not all), land administration used ground-based survey and methods: the application of photogrammetry and remote sensing was said to be far more contemporary, if not considered inappropriate by some practitioners, only commencing later into the 20th century. This paper sought to counter this prevailing view, and contended that the use of remote sensing and photogrammetry to support land administration was far from a recent addition to the land administration toolkit: scaled implementation dated back much earlier.

Using now more accessible historical works, made available through archive digitisation, this paper presented an enriched and more complete synthesis of the developments of photogrammetric methods and remote sensing applied to the domain of land administration. Developments from early phototopography and aerial surveys, through to numeric photogrammetric methods, the emergence of satellite remote sensing, digital computing, and later lidar surveys, UAVs, and artificial intelligence were covered. That said, the review has limitations in terms of relevant languages covered (e.g., German was not included), and being based upon the available literature. It is encouraged for others to undertake similar studies, where deemed necessary, of other language groups, and to undertake a more complete country-level comparison of remote sensing and photogrammetric techniques, and related laws, applied in land administration.

The synthesis illustrated how declarations of the benefits of the technique are hardly new-and neither are well-meaning, though oft-flawed, comparative analyses based on time, cost, coverage, and quality. The historic case for, and application of, photogrammetric and remote sensing methods, in land administration is undisputable. Alongside this key finding, this review also identified other recurring challenges, in selected country contexts, throughout the decades, including: the problem of land sector inertia, conservatism and legal constraints when it comes to imagery-based approaches; the recognition that invisible boundaries will always mean some boundaries can only be identified through human interaction; and more recently the increasing irrelevance of the distinction between ground and aerial survey methods: technology convergence is driving fusion in practice and educational programs.

Apart from providing this more holistic view and a timely and important reminder of previous pioneering work, the paper brought contemporary practical value in further demonstrating to land administration practitioners that aerial and remote methods of data capture, and subsequent map production, are an entirely legitimate, if not essential part of the domain. Any contemporary arguments that the tools and approaches do not bring adequate quality for land administration purposes cannot be sustained. Indeed, these arguments tend to undermine what should be essential characteristics of the land surveying profession-pragmatic and pioneering mindsets. That said, it is left to land administration practitioners to assess whether the available methods are suitable for a given jurisdiction, and also whether cadastral laws and standards require revisiting.

Author Contributions: Conceptualisation, R.M.B.; methodology, R.M.B.; validation, M.K., K.A.; formal analysis, R.M.B.; investigation, R.M.B., M.K.; resources, R.M.B., M.K.; data curation, R.M.B. and M.K.; writing—original draft preparation, R.M.B.; writing-review and editing, M.K. and K.A.; visualisation, M.K. and R.B; All authors have read and agreed to the published version of the manuscript.

Funding: This research received no external funding.

Institutional Review Board Statement: Not applicable.

Informed Consent Statement: Not applicable.

Data Availability Statement: Not applicable. 
Acknowledgments: In this section, you can acknowledge any support given which is not covered by the author contribution or funding sections. This may include administrative and technical support, or donations in kind (e.g., materials used for experiments).

Conflicts of Interest: The authors declare no conflict of interest.

\section{References}

1. Dale, P.; McLaughlin, J. Land Administration; Oxford University Press: Oxford, UK, 2000.

2. Henssen, J. Land Registration and Cadastre Systems: Principles and Related Issues. In Lecture Notes of Technische Universität München; Technische Universität München: München, Germany, 2010.

3. Konecny, G. Geoinformation: Remote Sensing, Photogrammetry and Geographic Information Systems; CRC Press: Boca Raton, FL, USA, 2014

4. Toth, C.; Jóźków, G. Remote sensing platforms and sensors: A survey. ISPRS J. Photogramm. Remote Sens. 2016, 115, 22-36. [CrossRef]

5. Bennett, R.; Oosterom, P.v.; Lemmen, C.; Koeva, M. Remote Sensing for Land Administration. Remote Sens. 2020, 12, 2497. [CrossRef]

6. Enemark, S.; Bell, K.C.; Lemmen, C.H.; McLaren, R. Fit-for-Purpose Land Administration; International Federation of Surveyors (FIG): Copenhagen, Denmark, 2014.

7. Rossiter, D.G. Research Concepts E Skills Volume 1: Concepts; ITC Faculty, The University of Twente: Enschede, The Netherlands, 2011; p. 35.

8. Kaushik, V.; Walsh, C.A. Pragmatism as a Research Paradigm and Its Implications for Social Work Research. Soc. Sci. 2019, 8, 255. [CrossRef]

9. Asiama, K.; Bennett, R.; Zevenbergen, J. Towards Responsible Consolidation of Customary Lands: A Research Synthesis. Land 2019, 8, 161. [CrossRef]

10. Bennett, R.; Unger, E.-M.; Lemmen, C.; Dijkstra, P. Land Administration Maintenance: A Review of the Persistent Problem and Emerging Fit-for-Purpose Solutions. Land 2021, 10, 509. [CrossRef]

11. Badampudi, D.; Wohlin, C.; Petersen, K. Experiences from using snowballing and database searches in systematic literature studies. In Proceedings of the 19th International Conference on Evaluation and Assessment in Software Engineering, Nanjing, China, 27 April 2015; pp. 1-10.

12. Martindale, A. The Country-Survey-Book: Or Land-Meters Vade-Mecum. Wherein the Principles and Practical Rules for Surveying of Land, Are ... Delivered ... With an Appendix, Containing Twelve Problems Touching Compound Interest and Annuities ... Illustrated with Copper Plates. Clavel, R., Sawbridge, T., Eds.; 1702. Available online: https:/ /quod.lib.umich.edu/e/eebo/A52120.0001.001?view=toc (accessed on 14 October 2021).

13. Love, J. Geodæsia: Or, The Art of Surveying and Measuring of Land, Made Easie. 1731. Available online: https://quod.lib.umich.edu/ e/eebo2/A49269.0001.001?view=toc (accessed on 14 October 2021).

14. Breaks, T. A Complete System of Land-surveying: Both in Theory and Practice: Containing the Best, the Most Accurate, and Commodious Methods of Surveying and Planning of Ground by All the Instruments Now in Use; Forgotten Books: London, UK, 1771.

15. Leybourn, W. The Compleat Surveyor: Or, The Whole Art of Surveying of Land: By a New Instrument Lately Invented; as Also by the Plain Table, Circumferentor, the Theodolite as Now Improv'd, Or by the Chain Only. Samuel Ballard ... , and Aaron Ward ..., and Tho. Woodward. 1722. Available online: https://books.googleusercontent.com/books/content?req=AKW5Qac9auCDImyAs4FEX4GemK0 WOiz2hn-bElmFE26UpCSPyzG-0DCtQW2aUpJbjG_uFPA7rzE-WK_kLV1Z1JRCsHr41Oj5dBpveWEtjjGYkQFbyDxorqr2BsfuD6 8o8nCi40i6P981nsI0qYiXvgVzKo79WjljSIF9yKnnSuAO6Rz0sx3EfYkdegH-hHIGHd1gRMgJliz4ce72uAXQuzN4K-YDjlMP6 (accessed on 20 October 2021).

16. Ainslie, J. Comprehensive Treatise on Land Surveying; Doig, S., Stirling, A., Eds.; Nabu Press: Charleston, SC, USA, 1812.

17. Thornthwaite, W.H. A Guide to Photography; Nabu Press: Charleston, SC, USA, 1845.

18. Lerebours, N.P. A Treatise on Photography: Containing the Latest Discoveries and Improvements Appertaining to the Daguerreotype; Longman, Brown, Green \& Longmans: London, UK, 1843.

19. Tissandier, G. A History and Handbook of Photography; Sampson, Low, Marston, Low, \& Searle: London, UK, 1877.

20. Reed, H.A. Photography Applied to Surveying; Wiley: New York, NY, USA, 1889.

21. Thomson, J. Photography and Exploration. In Proceedings of the Royal Geographical Society and Monthly Record of Geography; Royal Geographical Society (with the Institute of British Geographers). Wiley: New York, NY, USA, 1891; Volume 13, pp. 669-675.

22. Deville, E. Photographic Surveying: Including the Elements of Descriptive Geometry and Perspective; Government Printing Bureau: Tokyo, Japan, 1895.

23. Wilson, C. Ordnance survey, methods and processes of the. RSA J. 1890, 39, 258. [CrossRef]

24. Palmer, H.S. The Ordnance Survey of the Kingdom: Its Objects, Mode of Execution, History, and Present Condition; Stanford, E., Ed.; Forgotten Books: London, UK, 1873.

25. James, C. On the Ordnance Survey. R. United Serv. Inst. J. 1859, 3, 28-38. [CrossRef]

26. Black, C.E. The Survey of India, 1892-1893. Geogr. J. 1894, 4, 31-33. [CrossRef] 
27. Comstock, C.B. Notes on European Surveys. 1876. Available online: https://books.google.co.jp/books?hl=en\&lr=\&id= cvwZUbHoPKMC\&oi=fnd\&pg=PA1\&dq=Notes+on+European+Surveys.+1876.+\&ots=WdTJ4jqjTO\&sig=Cn7TBbChzZPhQczyUsQ2 7CGseDM\&redir_esc=y\#v=onepage\&q=Notes\%20on\%20European\%20Surveys.\%201876.\&f=false (accessed on 18 October 2021).

28. Flemer, J.A. Phototopography. Science 1895, 2, 152-154. [CrossRef] [PubMed]

29. Thompson, F.V. Stereo-photo surveying. Geogr. J. 1908, 31, 534-549. [CrossRef]

30. Atkinson, K.B. Vivian Thompson (1880-1917): Not only an officer of the Royal Engineers. Photogramm. Rec. 1980, 10, 5-38. [CrossRef]

31. Gill, D.; Hills, M.; Close, M. Stereo-Photo Surveying: Discussion. Geogr. J. 1908, 31, 549-551. [CrossRef]

32. Johnston, D. Surveys and Maps. Bull. Am. Geogr. Soc. 1909, 41, 751-754. [CrossRef]

33. Johnston, D. The Survey and Mapping of New Areas. Geogr. J. 1909, 34, 423-431. [CrossRef]

34. MacLeod, M.N. Mapping from air photographs. Geogr. J. 1919, 53, 382-396. [CrossRef]

35. Hinks, A.R. German war maps and survey. Geogr. J. 1919, 53, 30-40. [CrossRef]

36. Winterbotham, H.S. Geographical work with the Army in France. Geogr. J. 1919, 54, 12-23. [CrossRef]

37. Winterbotham, H.S. British survey on the Western Front. Geogr. J. 1919, 53, 253-271. [CrossRef]

38. Whitlock, G.F.; Newcombe, L.C.; Salmon, L.C.; Brock, M.; Holdich, T.; Hinks, M.; Hardy, G.; MacLeod, M.N. Mapping from Air Photographs: Discussion. Geogr. J. 1919, 53, 396-403. [CrossRef]

39. Newcombe, S.F. The practical limits of aeroplane photography for mapping. Geogr. J. 1920, 56, 201-206. [CrossRef]

40. Winterbotham, H.S. The Economic Limits of Aeroplane Photography for Mapping, and Its Applicability to Cadastral Plans. Geogr. J. 1920, 56, 481-483. [CrossRef]

41. Thomas, H.H. Aircraft photography in war and peace. Lecture III. Aeroplane photography in time of peace. J. R. Soc. Arts 1920, $68,777-781$.

42. Dodds, J.S. The Government Mapping Program in a Map-Minded Age. Science 1930, 71, 471-474. [CrossRef]

43. Australian Survey Committee. Report on the Need for a Geodetic and Topographical Survey of Australia. Aust. Surv. 1929, 2, 6-19. [CrossRef]

44. Winterbotham, H.S. General principles of photographic surveying. Trans. Opt. Soc. 1925, 27, 65. [CrossRef]

45. Dowson, E.M. Further notes on aeroplane photography in the Near East. Geogr. J. 1921, 58, 359-370. [CrossRef]

46. Bagley, J.W. Concerning aerial photographic mapping: A review. Geogr. Rev. 1922, 12, 628-635. [CrossRef]

47. Bergen, G.T. Closure to "Bergen on Aeroplane Topographic Surveys". Trans. Am. Soc. Civ. Eng. 1927, 90, 672-679. [CrossRef]

48. Tuttle, A.S.; Olmsted, F.L.; Green, C.N.; Ripley, T.M. Discussion of "Tuttle on Aerial Surveys for City Planning". Trans. Am. Soc. Civ. Eng. 1927, 91, 326-331. [CrossRef]

49. Burchall, P.R. An investigation of the possibilities attaching to aerial co-operation with survey, map-making and exploring expeditions. R. United Serv. Institution. J. 1922, 67, 112-127. [CrossRef]

50. Durward, J. Air Photography Surveys. Aeronaut. J. 1930, 34, 344-358. [CrossRef]

51. Winterbotham, H.S. The Surveys of Canada. Geogr. J. 1926, 67, 403-416. [CrossRef]

52. Fiske, H.C.; Davis, A.P.; Faison, H.R.; Matthes, G.H. Discussion of "Fiske on Aeroplane Topographic Surveys". Trans. Am. Soc. Civ. Eng. 1927, 90, 656-672. [CrossRef]

53. Spender, M. The New Photographic Survey of Switzerland. Geogr. J. 1932, 79, 383-397. [CrossRef]

54. Ripley, T.M.; Reading, O.S.; Stewart, L.O.; Peters, F.H.; Crosson, W.H.; Johns, D.F.; Nelles, D.H.; Ballester, R.E.; Pendleton, T.P.; Lemberger, O.; et al. Ripley on Stereo-Topographic Mapping. Trans. Am. Soc. Civ. Eng. 1933, 98, 795-822. [CrossRef]

55. Le Divelec, G.P. Aerophotogrammetry applied to the survey of large areas at mean scale. Photogrammetria 1950, 7, 40-43. [CrossRef]

56. Anderson, D.J. Aerial surveying. (Includes bibliography, photographs and plates). Sel. Eng. Pap. 1932, 1. [CrossRef]

57. Wolff, N. Air Survey and Colonial Cadastral Mapping. Emp. Surv. Rev. 1938, 4, 281-290. [CrossRef]

58. Salmon, F.J. Cadastral Air Survey. Emp. Surv. Rev. 1938, 4, 334-338. [CrossRef]

59. Eden, J.A. Air Survey and the Photograph. Emp. Surv. Rev. 1933, 2, 105-108. [CrossRef]

60. Winterbotham, H.S. Mapping of the colonial empire. Scott. Geogr. Mag. 1936, 52, 289-299. [CrossRef]

61. HLC; JEEC; EMD. Conference of empire survey officers 1931: Report of proceedings. Emp. Surv. Rev. 1933, 2, 108-120. [CrossRef]

62. Hinks, A.R. The Fifth International Congress of Photogrammetry, Rome, 1938. Geogr. J. 1939, $240-246$.

63. Birdseye, C.H. Stereoscopic phototopographic mapping. Ann. Assoc. Am. Geogr. 1940, 30, 1-24. [CrossRef]

64. Follet, F.W. Aerial photography and its application to surveying. Aust. Surv. 1938, 7, 37-41. [CrossRef]

65. None. New Zealand, department of lands and survey, annual report on surveys, 1943-1944. Emp. Surv. Rev. 1945, 8, 115-118.

66. None. Report of the survey of jamaica for 1941-42. Emp. Surv. Rev. 1943, 7, 168-182.

67. Vance, T.A. Mapping a Continent. Aust. Surv. 1940, 8, 148-156. [CrossRef]

68. Marschner, F.J. Maps and a Mapping Program for the United States. Ann. Assoc. Am. Geogr. 1943, 33, 199-219. [CrossRef]

69. None. Military Surveys. Emp. Surv. Rev. 1941, 6, 96-101.

70. Jones, S.B. The description of international boundaries. Ann. Assoc. Am. Geogr. 1943, 33, 99-117. [CrossRef]

71. Winterbotham, H.S. The international boundaries of Europe. Emp. Surv. Rev. 1945, 8, 133-137. [CrossRef]

72. Cheetham, G. The post-war programme of the ordnance survey of Great Britain. Emp. Surv. Rev. 1945, 8, 93-102. [CrossRef] 
73. El-Ricaby, A.; Velmonte, J.E.; Costa, A.; Dantwala, M.L.; Romero, C. First World Land Tenure Problems Conference and Report of Its Steering Committee. Land Econ. 1952, 28, 75-81. [CrossRef]

74. Thome, J.R. The process of land reform in Latin America. Wis. L. Rev. 1968, 9. Available online: https://heinonline.org/HOL/ LandingPage?handle=hein.journals $/$ wlr1968amp;div=10amp;id=amp;page $=($ accessed on 18 October 2021).

75. Dowson, E.M. Direct use of air photographs for cadastral purposes in Zanzibar. Emp. Surv. Rev. 1947, 9, 2-14. [CrossRef]

76. Smith, W.P.; Whittaker, B.B. Photogrammetry and land tenure surveys with particular reference to Uganda. Photogramm. Rec. 1959, 3, 42-54. [CrossRef]

77. Menzies, G.H. Monthly Notes of the Astronomical Society of South Africa. Land Surv. 1950, 9, 24.

78. Adams, L.P. The Computation of Aerial Triangulation for the Control of Cadastral Mapping in High Density Agricultural Areas. Ph.D. Thesis, University of East Africa, Kampala, Uganda, 1969.

79. Park, B.C. Use of Photo Mosaics as a Base for Range Resource Iventory in the Hashemite Kingdom of the Jordan. Rangel. Ecol. Manag. /J. Range Manag. Arch. 1955, 8, 257-260.

80. Van Zandt, F.K. A Photogrammetric Cadastral Survey in Utah. Photogramm. Eng. 1959, $23,493$.

81. Loelkes, G.L., Jr. Orthophotography as a Data Base for Land Descriptions. Can. Surv. 1969, 23, 54-60. [CrossRef]

82. Steiner, D. Use of air photographs for interpreting and mapping rural land use in the United States. Photogrammetria 1965, 20, 65-80. [CrossRef]

83. McVay, D.M. Cadastral Surveys by Photogrammetry. Highway Research Record. 1967. Available online: https://onlinepubs.trb. org/Onlinepubs/hrr/1967/201/201-004.pdf (accessed on 18 October 2021).

84. Andrews, G.S. Some statutory aspects in cadastral use of photogrammetry. Can. Surv. 1960, 15, 309-316. [CrossRef]

85. Slessor, D.R. Use of Photogrammetry on a Legal Survey. Can. Surv. 1959, 14, 330-336. [CrossRef]

86. Fitchett, D.A. Cadastral Systems on the Northern Coast of Peru: Some Problems and Proposals. J. Inter-Am. Stud. 1964, 6, 537-547. [CrossRef]

87. Osterhoudt, F. Land Titles in Northeast Brazil; The Use of Aerial Photography. Land Econ. 1965, 41, 387-392. [CrossRef]

88. Marzan, G.T.; Umadhay, G.; Jimenez, T.C. Philippine-Numerical Photogrammetric Cadastre. Photogramm. Eng. 1964, 30, $278-283$.

89. Oshima, T. Photogrammetry on Japan National Report of Japan. J. Jpn. Soc. Photogramm. 1973, 11, 61-77. [CrossRef]

90. Koffman, L.A. Photogrammetry for Land Reform, Vietnam. Mil. Eng. 1970, 62, 188-191.

91. Eekhout, L. Photogrammetry and the cadastral system: A paper presented to the 9th Survey Congress, Perth, April, 1966. Aust. Surv. 1966, 21, 909-924. [CrossRef]

92. Lee, B.J. Application of photogrammetry to cadastral surveying. Aust. Surv. 1965, 20, 515-518. [CrossRef]

93. Rassaby, H.S. Some applications of photogrammetry in engineering and cadastral surveying in New South Wales. Cartography 1960, 3, 145-151. [CrossRef]

94. Whitmore, G.D. Fifty Years in Surveying-Mapping-and the Future. J. Surv. Mapp. Div. 1969, 95, 143-150. [CrossRef]

95. Hart, C.A. Air Survey: The Modern Aspect. Geogr. J. 1946, 108, 179-198. [CrossRef]

96. Van der Weele, A.J. Graphical or numerical photogrammetry. Photogrammetria 1959, 16, 90-96. [CrossRef]

97. Petrie, G. The President's Prize Essay. Photogramm. Rec. 1959, 3, 125-138. [CrossRef]

98. Holden, G.J. Integrated surveys and large scale mapping. Aust. Surv. 1970, 23, 15-20. [CrossRef]

99. Basye, A.; Ul, A. Procedures and Standards for a Multipurpose Cadastre. By the Panel on a Multipurpose Cadastre, Committee on Geodesy; Commission on Physical Sciences, Mathematics, and Resources, National Research Council; National Academy Press: Washington, DC, USA, 1983.

100. Bonacci, F. Problems in Property Surveys and Right-of-Way Maps. J. Surv. Mapp. Div. 1963, 89, 91-112. [CrossRef]

101. Schermerhorn, W. Planning in modern aerial survey. Photogrammetria 1960, 17, 7-17. [CrossRef]

102. Weatherhead, T.D. The Application of Air Survey to the Economic Development of a Country. Aeronaut. J. 1955, 59, 682-689. [CrossRef]

103. Robertson, V.C. Aerial photography and proper land utilisation. Photogramm. Rec. 1955, 1, 5-12. [CrossRef]

104. Biesheuvel, H. Maps and land use. Emp. Surv. Rev. 1956, 13, 342-353. [CrossRef]

105. Einevoll, O. Land classification maps of areas basic to agricultural production. Nor. J. Geogr. 1968, 22, 4. [CrossRef]

106. EMD; VLOS. A bibliography of cadastral survey and land records. Emp. Surv. Rev. 1946, 8, 210-214. [CrossRef]

107. Dowson, E.M.; Sheppard, V.L. Evolution of land records. Emp. Surv. Rev. 1948, 9, 295-311. [CrossRef]

108. HBT; BW; EAM; PNR. Land registration. Emp. Surv. Rev. 1953, 12, 87-95. [CrossRef]

109. Schermerhorn, W.; Witt, G.F. Photogrammetry for cadastral survey. Photogrammetria 1953, 10, 45-57. [CrossRef]

110. Hart, C.A. Modern Influences on the University Aspect of Professional Training in Surveying. Emp. Surv. Rev. 1948, 9, $282-295$. [CrossRef]

111. Ray, P.N. Surveying instruction at the university. Emp. Surv. Rev. 1953, 12, 104-110. [CrossRef]

112. Angus-Leppan, P.V. University education and the modern surveyor: A paper read at the Annual Congress of the Institution of Surveyors of Australia, Perth, April, 1966. Aust. Surv. 1966, 21, 833-846. [CrossRef]

113. Abrams, M.M. Photogrammetry and Highway Law. J. Surv. Mapp. Div. 1964, 90, 153-168. [CrossRef]

114. Irving, G.C. Photogrammetric techniques in land title boundary surveys: An address given to the NSW Division on 13th November, 1959. Aust. Surv. 1960, 18, 154-160. [CrossRef]

115. Thompson, E.H. The prospect for British photogrammetry. Photogramm. Rec. 1958, 2, 355-362. [CrossRef] 
116. Ovington, J.J. Photogrammetry and the private surveyor: A paper given to the NSW Division by JJ Ovington, Assoc. IS Aust., MAIC on 10th July, 1959. Aust. Surv. 1960, 18, 53-57. [CrossRef]

117. Bress, D.L. Computers and Cartography. Computer 1972, 5, 44-47. [CrossRef]

118. Dale, P.F. A Systems view of the Cadastre. Surv. Rev. 1979, 25, 28-32. [CrossRef]

119. Hardy, E.E.; Anderson, J.R. A Land Use Classification System for Use with Remote-Sensor Data. Available online: https: //pubs.usgs.gov/pp/0964/report.pdf (accessed on 18 October 2021).

120. Mullens, R.H.; Senger, L.W.; Thrower, N.J.; Walton, K.J. Satellite Photography as a Geographic Tool for Land Use Mapping of the Southwestern United States Technical Report, 1 July 1968-31 January 1970; United States Department of Interior, Geological Survey, for NASA: Washington, DC, USA, 1970.

121. Kio, P.R. Developing Countries and the new science of remote sensing. Commonw. For. Rev. 1974, 53, 137-145.

122. Torbert, G.B.; Woll, A.M. Remote sensing on Indian and public lands. In NASA. Manned Spacecraft Center 4 th Ann. Earth Resources Program Rev. 1972; 2. Available online: https:/ / ntrs.nasa.gov/citations/19720021712 (accessed on 20 October 2021).

123. Lambert, B.P. The impact of satellites on mapping. Aust. Surv. 1973, 25, 303-315. [CrossRef]

124. Kellie, A.C.; AC, K. Evaluation of Remote Sensing Imagery for Cadastral Mapping. Available online: http:/ / pascal-francis.inist. $\mathrm{fr} /$ vibad/index.php?action=getRecordDetail\&idt=PASCAL7930209581 (accessed on 18 October 2021).

125. McLaughlin, J. The Cadastral Surveying Challenge. Can. Surv. 1975, 29, 131-136. [CrossRef]

126. Harley, I.A. The determination of XYZ coordinates using numerical photogrammetry. Aust. Surv. 1973, 25, 89-108. [CrossRef]

127. McLaughlin, J.D. The Nature, Function and Design Concepts of Multi-Purpose Cadastres; The University of Wisconsin-Madison: Madison, WI, USA, 1975.

128. Cook, R.N. Land Data Systems: The Next Steps. U. Cin. L. Rev. 1974, 43, 527.

129. Smith, W. The Presentation of Spatial Information. InNatural Resources Forum; Blackwell Publishing Ltd.: Oxford, UK, 1977; Volume 1, pp. 203-213.

130. Braasch, H.W. The arrangement of numerical cadastral data in a modern cadastre of land holdings. Can. Surv. 1975, 29, 39-48. [CrossRef]

131. Gilliam, J.J. Aerial Photography and Related Products I Aids in Expediting the Construction and Development of Urban Land-Use Maps. Available online: https: / / scholarworks.umt.edu/cgi/viewcontent.cgi?article=2501\&context=etd (accessed on 19 October 2021).

132. Blachut, T.J.; Chrzanowski, A.; Saastamoinen, J.H. Use of Photogrammetry in Urban Areas. In Urban Surveying and Mapping; Springer: New York, NY, USA, 1979; pp. 246-329.

133. Jaksic, Z. Photogrammetric Data in Urban Information Systems. Can. Surv. 1972, 26, 558-566. [CrossRef]

134. Weissmann, K. Photogrammetry applied to cadastral survey in Switzerland. Photogramm. Rec. 1971, 7, 5-15. [CrossRef]

135. Bonnell, C. Photomapping and Its Application to Legal Surveys. Can. Surv. 1977, 31, 331-346. [CrossRef]

136. Leatherdale, J.; Kennedy, R. Mapping Arabia. Geogr. J. 1975, 141, 240-251. [CrossRef]

137. Blachut, T.J. Winter Photographs in Cadastral Surveying (A Suggestion). Can. Surv. 1971, 25, 603-612. [CrossRef]

138. Lafferty, M.E. Accuracy/Costs with Analytics. Photogramm. Eng. 1973, 39, 507-514.

139. Dale, P.F. Cadastres and Cadastral maps. Cartogr. J. 1977, 14, 44-48. [CrossRef]

140. Barrie, J.K. Land registration and boundary surveys. Aust. Surv. 1977, 28, 256-262. [CrossRef]

141. Forster, B.C. An introduction to modern Remote Sensing techniques and their implication for surveying practice. Aust. Surv. 1989, 34, 763-779. [CrossRef]

142. Andersson, U.; Rystedt, B. Scandinavian Activities in the LIS/GIS Area. Photogramm. Eng. Remote Sens. 1988, 54, $201-204$.

143. Lodwick, G.D.; Paine, S.H. Satellite remote sensing in surveying present opportunities, future possibilities. Can. Surv. 1986, 40, 315-326. [CrossRef]

144. Zhou, Q. A method for integrating remote sensing and geographic information systems. Photogramm. Eng. Remote Sens. 1989, 55, 591-596.

145. Cooperative, G.I.; Collins, F. The unique qualities of a geographic information system: A commentary. Photogramm. Eng. Remote Sens. 1988, 54, 1547-1549.

146. Dale, P.F.; McLaughlin, J.D. Land Information Management; Oxford University Press: Oxford, UK, 1988.

147. Muzakidis, P.D. Photogrammetric Mapping for Cadastral Land and Information Systems; University of London, University College London: London, UK, 1990.

148. Gagnon, R. Cadastral plotting by similarity transformation. CISM J. 1988, 42, 121-125. [CrossRef]

149. Visser, J. The European Organisation for Experimental Photogrammetric Research (OEEPE). Photogramm. Rec. 1982, 10, 655-668. [CrossRef]

150. Walker, A.S. A review of map revision by photogrammetry. Photogramm. Rec. 1984, 11, 395-405. [CrossRef]

151. Or, K. The Prototype Land Information System for the Cadastral Pilot Project in Colombia. In Auto-Carto Six: Automated Cartography: International Perspectives on Achievements and Challenges: Proceedings of the Sixth International Symposium on Automated Cartography, October 16-21, National Capital Region of Canada, Canada 1983; Steering Committee for the Sixth International Symposium on Automated Cartography= Comité organisateur pour le sixième Symposium sur la Cartographie Automatisée; American Congress on Surveying and Mapping: Frederick, MD, USA, 1983; Volume 1, p. 128.

152. Clerici, E.; Walker, E. Photogrammetric cadastral mapping in rural Taïwan. Aust. Surv. 1987, 33, 469-479. [CrossRef] 
153. Cremont, D. Application of Computer Technology in Processing of Cadastral Surveying and Mapping Data. Can. Surv. 1980, 34, 21-40. [CrossRef]

154. Smith, G.L.; Nisbet, K.A. Geodetic network densification by analytical aerial triangulation. Aust. Surv. 1985, 32, 644-657. [CrossRef]

155. Ziemann, H. High Accuracy Photogrammetric Determinations Using Image Deformation Corrections. Can. Surv. 1980, 34, 65-74. [CrossRef]

156. Karns, D.O. Photogrammetric cadastral surveys and GLO corner restoration. Photogramm. Eng. Remote Sens. 1981, 47, 193-198.

157. Blachut, T.J. Cadastre for developing countries based on orthophoto techniques. Can. Surv. 1985, 39, 31-43. [CrossRef]

158. Williamson, I.P. Cadastral survey techniques in developing countries-with particular reference to Thailand. Aust. Surv. 1983, 31, 496-512. [CrossRef]

159. Bujakiewicz, A. Simple Photogrammetric Methods for Registration of rural land in African countries. In Technical Commission IV: Cartographic and Data Bank Application of Photogrammetry and Remote Sensing; ISPRS: Kyoto, Japan, 1-10 July 1988.

160. Van Loenen, B. Land Tenure in Zambia. 1999. Available online: http:/ / citeseerx.ist.psu.edu/viewdoc/download?doi=10.1.1.460.7 $561 \&$ rep $=$ rep $1 \&$ type $=$ pdf (accessed on 18 October 2021).

161. Williamson, I.P. The cadastral survey requirements of developing countries in the pacific regionwith particular reference to fiji. Surv. Rev. 1982, 26, 355-366. [CrossRef]

162. Hannigan, B.J. The role of surveying in society—has it changed? Aust. Surv. 1990, 35, 209-228. [CrossRef]

163. Gracie, G. Restructuring Photogrammetry and Remote Sensing Education for the Future. Can. Surv. 1985, 39, 338-344. [CrossRef]

164. Forster, B.C.; Williamson, I.P. Past and Future Trends of Surveying Education in Australia. Can. Surv. 1985, 39, 427-435. [CrossRef]

165. Bédard, Y.; Gagnon, P.; Gagnon, P.A. Modernizing surveying and mapping education: The programs in geomatics at laval university. CISM J. 1988, 42, 105-114. [CrossRef]

166. Dale, P.F. Evolution and developments in cadastral studies. Can. Surv. 1985, 39, 353-362. [CrossRef]

167. Paulsson, B.; Mundial, B. Urban Applications of Satellite Remote Sensing and GIS Analysis; World Bank: Washington, DC, USA, 1992.

168. Dale, P. Is technology a blessing or a curse in land administration. In Proceedings of the UN-FIG Conference on Land Tenure and Cadastral Infrastructure for Sustainable Development, Melbourne, Australia, 25 October 1999; pp. 25-27.

169. Jensen, J.R.; Cowen, D.C. Remote sensing of urban/suburban infrastructure and socio-economic attributes. Photogramm. Eng. Remote Sens. 1999, 65, 611-622.

170. Rao, M.; Krishnamurthy, J.; Raj, U.; Patan, S.K.; Ragavaswamy, V.; Jayaraman, V. Classification of high resolution satellite imagery-The experience from IRS-1C/1D. In Proceedings of the IAF, International Astronautical Congress 49th, Melbourne, Australia, 2 October 1998.

171. Rao, D.P.; Navalgund, R.R.; Murthy, Y.K. Cadastral applications using IRS-1C data-Some case studies. Curr. Sci. 1996, 70, 624-628.

172. Das, R.K.; Ghosh, S.; Rajesh, K.; Prithviraj, M. Cadastral map overlaying upon irs-ic. 8ybrid image: A critical analysis. Geogr. Environ. 1997, 2, 53-58.

173. González, A.R. Horizontal Accuracy Assessment of the New Generation of High Resolution Satellite Imagery for Mapping Purposes. Master's Thesis, Ohio State University, Columbus, OH, USA, 1998.

174. Schmitt, U.; Sulzer, W.; Schardt, M. Analysis of settlement structure by means of high resolution satellite imagery. Int. Arch. Photogramm. Remote Sens. 1998, 32, 557-561.

175. Leberl, F.; Kalliany, R. Earth Observation Data Services for Users-an Austrian Perspective. In ESRIN EEOS Workshop on Networks. In Proceedings of the ESRIN EEOS Workshop on Networks, Frascati, Italy, 13-15 December 1994; pp. 461-469.

176. Baltsavias, E.P. Digital ortho-images-A powerful tool for the extraction of spatial-and geo-information. ISPRS J. Photogramm. Remote Sens. 1996, 51, 63-77. [CrossRef]

177. Chagarlamudi, P.; Plunkett, G.W. Mapping applications for low-cost remote sensing and geographic information systems. Int. J. Remote Sens. 1993, 14, 3181-3190. [CrossRef]

178. Konecny, G. International Technical Cooperation in the Geoinformatics Field. In Proceedings of the EARSeL Workshop on Remote Sensing in the Developing Countries, Gent, Belgium, 19 September 2000.

179. Leka, E.; Gjika, M. Aerial Photography and Parcel Mapping for Immovable Property Registration in Albania. Available online: https: / / minds.wisconsin.edu/bitstream/handle/1793/69877/wp10.pdf?sequence=1 (accessed on 18 October 2021).

180. Holstein, L. Towards best practice from World Bank experience in land titling and registration. In Proceedings of the International Conference on Land Tenure and Administration, November 1996; pp. 1-26. Available online: https://citeseerx.ist.psu.edu/ viewdoc / download?doi=10.1.1.472.1914\&rep=rep1\&type=pdf (accessed on 18 October 2021).

181. Fourie, C.; Nino-Fluck, O. Cadastre and land information systems for decision makers in the developing world. Geomatica 2000, 54, 335-343.

182. Anderson, P.S. Mapping land rights in Mozambique. Photogramm. Eng. Remote Sens. 2000, 66, 769-776.

183. Christensen, S.F.; Werner, W.; Højgaard, P.D. Innovative land surveying and land registration in Namibia; University College London: London, UK, 1999.

184. Al-garni, A.M. Urban photogrammetric data base for multi-purpose cadastral-based information systems: The Riyadh city case. ISPRS J. Photogramm. Remote Sens. 1996, 51, 28-38. [CrossRef]

185. Harcombe, P.R.; Williamson, I.P. A cadastral model for low value lands: The NSW western lands experience. In Proceedings of the FIG XXI International Congress, Brighton, UK, 19-25 July 1998. 
186. Boatto, L.; Consorti, V.; Del Buono, M.; Di Zenzo, S.; Eramo, V.; Esposito, A.; Melcarne, F.; Meucci, M.; Morelli, A.; Mosciatti, M.; et al. An interpretation system for land register maps. Computer 1992, 25, 25-33. [CrossRef]

187. Mohamed, M.A.; Ventura, S.J. Use of geomatics for mapping and documenting indigenous tenure systems. Soc. Nat. Resour. 2000, 13, 223-236. [CrossRef]

188. Ehlers, M. Remote Sensing and Geographic Information Systems: Image-Integrated Geographic Information Systems. In Geographic Information Systems (GIS) and Mapping_Practices and Standards 1992 Jan; ASTM International: West Conshohocken, PA, USA, 1992.

189. Onsrud, H.J. Integrated cadastral technologies field system (ictfs) for documenting title and boundary evidence. Geomatica 1998, $52,25-35$.

190. Mason, S.O.; Fraser, C.S. Image sources for informal settlement management. Photogramm. Rec. 1998, 16, 313-330. [CrossRef]

191. Bartl, R.; Petrou, M.; Christmas, W.J.; Palmer, P.L. Automatic registration of cadastral maps and Landsat TM images. In Image and Signal Processing for Remote Sensing III; International Society for Optics and Photonics: Bellingham, WA, USA, 1996; Volume 2955, pp. 9-20.

192. Pinz, A.J.; Prantl, M. Active fusion for remote sensing image understanding. In Image and Signal Processing for Remote Sensing II; International Society for Optics and Photonics: Bellingham, WA, USA, 1995; Volume 2579, pp. 67-77.

193. Okpala, D.C. Land survey and parcel identification: Data for effective land management. Land Use Policy 1992, 9, 92-98. [CrossRef]

194. Zevenbergen, J.; De Vries, W.; Bennett, R.M. (Eds.) Advances in Responsible Land Administration; CRC Press: Boca Raton, FL, USA, 2015

195. Polat, Z.A. Evolution and future trends in global research on cadastre: A bibliometric analysis. GeoJournal 2019, 84, 1121-1134. [CrossRef]

196. Reis, S.; Torun, A.T.; Bilgilioğlu, B.B. Investigation of Availability of Remote Sensed Data in Cadastral Works. In Cadastre: Geo-Information Innovations in Land Administration; Springer: Cham, Switzerland, 2017; pp. 63-76.

197. Jarica, C.C. Commercialization of High-Resolution Earth Observation Satellite Remote Sensing; Florida Atlantic University: Boca Raton, FL, USA, 1996.

198. Şahin, N.; Bakıc1, S.; Erkek, B. An Investigation on High Resolution IKONOS Satellite Images for Cadastral Applications. Available online: https: / / cartesia.org/geodoc/isprs2004/comm7/papers/222.pdf (accessed on 18 October 2021).

199. Fraser, C.; Tshering, D.; Grün, A. Satellite Mapping in Bhutan. GIM Int. 2008, 22, 18-24.

200. Ali, Z. Assessing Usefulness of High-Resolution Satellite Imagery (HRSI) in GIS-based Cadastral Land Information System. J. Settl. Spat. Plan. 2012, 3, 93-96.

201. Ali, Z.; Tuladhar, A.; Zevenbergen, J. An integrated approach for updating cadastral maps in Pakistan using satellite remote sensing data. Int. J. Appl. Earth Obs. Geoinf. 2012, 18, 386-398. [CrossRef]

202. Rao, S.S.; Sharma, J.R.; Rajasekhar, S.S.; Rao, D.S.; Arepalli, A.; Arora, V.; Singh, R.P.; Kanaparthi, M. Assessing usefulness of High-Resolution Satellite Imagery (HRSI) for re-survey of cadastral maps. ISPRS Ann. Photogramm. Remote Sens. Spat. Inf. Sci. 2014, 2, 133-143. [CrossRef]

203. Kumar, K.E.M.; Singh, S.; Attri, P.; Kumar, R.; Kumar, A.; Hooda, R.S.; Sapra, R.K.; Garg, V.; Kumar, V.; Sarika; et al. GIS based Cadastral level Forest Information System using World View-II data in Bir Hisar (Haryana). ISPRS Int. Arch. Photogramm. Remote Sens. Spat. Inf. Sci. 2014, XL-8, 605-612. [CrossRef]

204. Sengupta, A.; Lemmen, C.; Devos, W.; Bandyopadhyay, D.; Van der Veen, A. Constructing a seamless digital cadastral database using colonial cadastral maps and VHR imagery-an Indian perspective. Surv. Rev. 2016, 48, 258-268. [CrossRef]

205. Panday, U.S.; Chhatkuli, R.R.; Joshi, J.R.; Deuja, J.; Antonio, D.; Enemark, S. Securing Land Rights for All through Fit-for-Purpose Land Administration Approach: The Case of Nepal. Land 2021, 10, 744. [CrossRef]

206. Andri, H.; Sella, N.; Alfita, P.; Putri, R.; Winna, P.P.; Lasmi, R.; Ratri, W.; Rani, A. Incremental Improvement of High resolution Satellite Imagery For Participatory Mapping in Land Registration. IOP Conf. Ser. Earth Environ. Sci. 2019, 280, 012035. [CrossRef]

207. Asiama, K.O.; Bennett, R.M.; Zevenbergen, J.A. Participatory Land Administration on Customary Lands: A Practical VGI Experiment in Nanton, Ghana. ISPRS Int. J. Geo-Inf. 2017, 6, 186. [CrossRef]

208. Balas, M.; Carrilho, J.; Lemmen, C. The Fit for Purpose Land Administration Approach-Connecting People, Processes and Technology in Mozambique. Land 2021, 10, 818. [CrossRef]

209. Ondulo, J.D.; Kalande, W. High spatial resolution satellite imagery for Pid improvement in Kenya. In Proceedings of the FIG Congress: Shaping the Change, Munich, Germany, 8 October 2006; pp. 8-13.

210. Lengoiboni, M.; Bregt, A.; van der Molen, P. Pastoralism within land administration in Kenya—The missing link. Land Use Policy 2010, 27, 579-588. [CrossRef]

211. Hassan, N.D.; Noori, A.M.; Hasan, S.F.; Shareef, M.A.; Ajaj, Q.M. Cadastral Mapping Accuracy Assessment Using Various Surveying Techniques and High-Resolution Satellites Images. In Proceedings of the 2019 2nd International Conference on Electrical, Communication, Computer, Power and Control Engi-neering (ICECCPCE), Mosal, Iraq, 13-14 February 2019; pp. 182-187.

212. Jones, B.; Lemmen, C.H.; Molendijk, M. Low Cost, Post Conflict Cadastre with Modern Technology. In Proceedings of the Responsible Land Governance, Towards and Evidence Based Approach, Washington, DC, USA, 20-24 March 2017; pp. 20-24.

213. Chen, J.; Dowman, I.; Li, S.; Li, Z.; Madden, M.; Mills, J.; Paparoditis, N.; Rottensteiner, F.; Sester, M.; Toth, C.; et al. Information from imagery: ISPRS scientific vision and research agenda. ISPRS J. Photogramm. Remote Sens. 2016, 115, 3-21. [CrossRef]

214. Cramer, M. Digital Camera Calibration; EuroSDR no 55; Gopher Amsterdam: Amsterdam, The Netherlands, 2011; 262p. 
215. Remondino, F.; Fraser, C. Digital camera calibration methods: Considerations and comparisons. In: The International Archives of Photogrammetry. Remote Sens. Spat. Inf. Sci 2006, XXXVl-5, 266-272.

216. Lowe, D.G. Distinctive Image Features from Scale-Invariant Keypoints. Int. J. Comput. Vis. 2004, 60, 91-110. [CrossRef]

217. Bay, H.; Ess, A.; Tuytelaars, T.; van Goal, L. SURF: Speeded up robust features. Comput. Vis. Image Und. 2008, 110, 346-359. [CrossRef]

218. Fischler, M.A.; Bolles, R.C. Random Sample Consensus: A Paradigm for Model Fitting with Applications to Image Analysis and Automated Cartography. Commun. ACM 1987, 726-740. [CrossRef]

219. Vosselman, G. Advanced point cloud processing. In Photogrammetric Week; Wichmann: Heidelberg, Germany, 2009; pp. 137-146.

220. Mountrakis, G.; Im, J.; Ogole, C. Support vector machines in remote sensing: A review. ISPRS J. Photogramm. Remote Sens. 2011, 66, 247-259. [CrossRef]

221. Gislason, P.O.; Benediktsson, J.A.; Sveinsson, J.R. Random Forests for land cover classification. Pattern Recognit. Lett. 2006, 27, 294-300. [CrossRef]

222. Lu, D.; Li, G.; Moran, E. Current situation and needs of change detection techniques. Int. J. Image Data Fusion 2014, 5, 13-38. [CrossRef]

223. Srinivas, P.; Venkataraman, V.R.; Jayalakshmi, I. Digital Aerial Orthobase for Cadastral Mapping. J. Indian Soc. Remote Sens. 2011, 40, 497-506. [CrossRef]

224. Ahn, K.; Song, Y. Digital Photogrammetry for Land Registration in Developing Countries Digital Photogrammetry for Land Registration in Developing Countries. In Proceedings of the FIG Working Week 2011 Bridging the Gap between Cultures, Marrakech, Morocco, 18-22 May 2011.

225. Offei, E.; Lengoiboni, M.; Koeva, M. Compliance with Residential Building Standards in the Context of Customary Land Tenure System in Ghana. Planext Next Gener. Plan. 2018, 6, 25-45. [CrossRef]

226. Tamrakar, R.M. A Prospect of Digital Airborne Photogrammetry Approach for Cadastral Mapping in Nepal. J. Geoinformatics Nepal 2012, 11, 1-6. [CrossRef]

227. Harintaka, S.; Susanto, A. Assessment of Low Cost Small Format Aerial Photogrammetry for Cadastral Mapping (Case Study in Klaten Regency, Central Java, Indonesia). In Proceedings of the Spatial Data Serving People, Land Governance and the Environment-Building the Capacity, Hanoi, Vietnam, 19-22 October 2009.

228. Burgos, A.S. Digital Mapping for Cadastral Purposes; ASPRS/MAPPS: Sanantonio, TX, USA, 2009.

229. Al-Ruzouq, R.; Dimitrova, P. 2006 Photogrammetric Techniques for Cadastral Map Renewal. In Proceedings of the XXIII FIG Congress, Munich, Germany, 8-13 October 2006.

230. Alkan, M.; Solak, Y. An investigation of 1: 5000 scale photogrammetric data for cadastral mapping uses: A case study of Kastamonu-Taskopru. Afr. J. Agric. Res. 2010, 5, 2576-2588.

231. Meixner, P.; Leberl, F. From aerial images to a description of real properties-A framework. In Proceedings of the International Conference on Computer Vision Theory and Applications_-Volume 2; VISAPP: Angers, France; SCITEPRESS-Science and Technology Publications: Setúbal, Portugal, 2010; pp. 283-291.

232. Siriba, D. Positional Accuracy Assessment of a Cadastral Dataset based on the Knowledge of the Process Steps used. In Proceedings of the 12th AGILE Conference on GIScience. Leibniz Universität Hannover, Germany. Available online: https: / / www.springer.com/gp/book/9783642003172 (accessed on 18 October 2021).

233. Mumbone, M. Innovations in Boundary Mapping: Namibia, Customary Land and UAV's. Master's Thesis, University of Twente, Enschede, The Netherlands, 2015.

234. Meijs, M.G.; Kapitango, D.; Witmer, R. Land Registration using aerial photography in Namibia: Costs and lessons. In Proceedings of the FIG-World Bank Conference on Land Governance in Support of the MDGs: Responding to New Challenges, Washington DC, USA, 9-10 March 2009.

235. Ramadhani, S.A.; Bennett, R.M.; Nex, F.C. Exploring UAV in Indonesian cadastral boundary data acquisition. Earth Sci. Inform. 2018, 11, 129-146. [CrossRef]

236. Yuwono, B.D.; Suprayogi, A.; Azeriansyah, R.; Nukita, D. UAV Photogrammetry Implementation Based on GNSS CORS UDIP to Enhance Cadastral Surveying and Monitoring Urban Development (Case Study: Ngresep Semarang). IOP Conf. Ser. Earth Environ. Sci. 2018, 165, 012031. [CrossRef]

237. Aditya, T.; Maria-Unger, E.; Berg, C.V.; Bennett, R.; Saers, P.; Syahid, H.L.; Erwan, D.; Wits, T.; Widjajanti, N.; Santosa, P.B.; et al. Participatory Land Administration in Indonesia: Quality and Usability Assessment. Land 2020, 9, 79. [CrossRef]

238. Kurczynski, Z.; Bakuła, K.; Karabin, M.; Kowalczyk, M.; Markiewicz, J.S.; Ostrowski, W.; Podlasiak, P.; Zawieska, D. The possibility of using images obtained from the uas in cadastral works. In Proceedings of the International Archives of the Photogrammetry, Remote Sensing \& Spatial Information Sciences, Prague, Czech Republic, 2-19 July 2016.

239. Cienciała, A.; Sobolewska-Mikulska, K.; Sobura, S. Credibility of the cadastral data on land use and the methodology for their verification and update. Land Use Policy 2021, 102, 105204. [CrossRef]

240. Kameri-Mbote, P.; Muriungi, M. Potential contribution of drones to reliability of Kenya's land information system. Afr. J. Inf. Commun. 2017, 20, 159-169. [CrossRef]

241. Wayumba, R.; Mwangi, P.; Chege, P. Application of unmanned aerial vehicles in improving land registration in Kenya. Int. J. Res. Eng. Sci. 2017, 5, 5-11. 
242. Koeva, M.; Muneza, M.; Gevaert, C.; Gerke, M.; Nex, F. Using UAVs for map creation and updating. A case study in Rwanda. Surv. Rev. 2018, 50, 312-325. [CrossRef]

243. Stöcker, C.; Ho, S.; Nkerabigwi, P.; Schmidt, C.; Koeva, M.; Bennett, R.; Zevenbergen, J. Unmanned Aerial System Imagery, Land Data and User Needs: A Socio-Technical Assessment in Rwanda. Remote Sens. 2019, 11, 1035. [CrossRef]

244. Flores, C.C.; Tan, E.; Buntinx, I.; Crompvoets, J.; Stöcker, C.; Zevenbergen, J. Governance assessment of the UAVs implementation in Rwanda under the fit-for-purpose land administration approach. Land Use Policy 2020, 99, 104725. [CrossRef]

245. Ali, F. Fit-for-Purpose Boundary Mapping and Valuation of Agricultural Land Using UAVs: The Case of a1 Farms in Zimbabwe. Master's Thesis, University of Twente, Enschede, The Netherlands, 2017.

246. Karataş, K.; Altinişik, N.S. The Effect of UAV Usage on Detail Points in Cadastre Update Studies: Çorum-Karaköy Case Study. Int. J. Environ. Geoinformatics 2020, 7, 140-146. [CrossRef]

247. Koeva, M.; Gasuku, O.; Lengoiboni, M.; Asiama, K.; Bennett, R.M.; Potel, J.; Zevenbergen, J. Remote Sensing for Property Valuation: A Data Source Comparison in Support of Fair Land Taxation in Rwanda. Remote Sens. 2021, 13, 3563. [CrossRef]

248. Mbarga, T.C. Advantages of a Digital Cadastre Using an Unmanned Aerial Vehicle (UAV) Tool to Support Better Governance and Land Administration in Cameroon: An Exploratory Study. Available online: https://fig.net/resources/proceedings/fig proceedings/fig2020/papers/ts01e/TS01E_tobie_camille_vivian_et_al_10715.pdf (accessed on 18 October 2021).

249. Stöcker, C.; Bennett, R.; Nex, F.; Gerke, M.; Zevenbergen, J. Review of the Current State of UAV Regulations. Remote Sens. 2017, 9, 459. [CrossRef]

250. Stoter, J.E.; van Oosterom, P. 3D Cadastre in an International Context: Legal, Organizational, and Technological Aspects; CRC Press: London, UK, 2006.

251. Van Oosterom, P.; Bennett, R.; Koeva, M.; Lemmen, C. 3D land administration for 3D land uses. Land Use Policy 2020, $98,104665$. [CrossRef]

252. Filin, S.; Borka, A.; Doytsher, Y. From 2D to 3D Land Parcelation: Fusion of LiDAR Data and Cadastral Maps. Surv. Land Inf. Sci. 2008, 68, 81-91.

253. Kodors, S.; Ratkevics, A.; Rausis, A.; Buls, J. Building Recognition Using LiDAR and Energy Minimization Approach. Procedia Comput. Sci. 2015, 43, 109-117. [CrossRef]

254. Kumar, P.; Rahman, A.A.; Buyuksalih, G. Automated Extraction of Buildings from Aerial Lidar Point Cloud and Digital Imaging Datasets for 3D Cadastre-Preliminary Results. In Cadastre: Geo-Information Innovations in Land Administration; Springer: Cham, Switzerland, 2017; pp. 159-165.

255. Giannaka, O.; Dimopoulou, E.; Georgopoulos, A. Investigation on the contribution of LiDAR data in 3D cadastre. Paphos, Cyprus. (RSCy2014). 2014, Volume 9229, p. 922905. Available online: https://www.researchgate.net/publication/269320030_ Investigation_on_the_contribution_of_LiDAR_data_in_3D_Cadastre (accessed on 18 October 2021).

256. Drobež, P.; Grigillo, D.; Lisec, A.; Fras, M.K. Remote sensing data as a potential source for establishment of the 3D cadastre in Slovenia. Géod. Vestn. 2016, 60. [CrossRef]

257. Luo, X.; Bennett, R.M.; Koeva, M.; Lemmen, C. Investigating Semi-Automated Cadastral Boundaries Extraction from Airborne Laser Scanned Data. Land 2017, 6, 60. [CrossRef]

258. Wierzbicki, D.; Matuk, O.; Bielecka, E. Polish Cadastre Modernization with Remotely Extracted Buildings from High-Resolution Aerial Orthoimagery and Airborne LiDAR. Remote Sens. 2021, 13, 611. [CrossRef]

259. Griffith-Charles, C.; Sutherland, M. 3D cadastres for densely occupied informal situations: Necessity and possibility. Land Use Policy 2020, 98, 104372. [CrossRef]

260. Lubeck, D. Airborne Dual-band Radar for Cadastre. Gim Int. Worldw. Mag. Geomat. 2016, 30, $26-27$.

261. Rajabifard, A.; Atazadeh, B.; Kalantari, M. BIM and Urban Land Administration; CRC Press: London, UK, 2019.

262. Koeva, M.; Nikoohemat, S.; Elberink, S.O.; Morales, J.; Lemmen, C.; Zevenbergen, J. Towards 3D Indoor Cadastre Based on Change Detection from Point Clouds. Remote Sens. 2019, 11, 1972. [CrossRef]

263. Bieda, A.; Bydłosz, J.; Warchoł, A.; Balawejder, M. Historical Underground Structures as 3D Cadastral Objects. Remote Sens. 2020, 12, 1547. [CrossRef]

264. Yan, J.; Jaw, S.W.; Soon, K.H.; Wieser, A.; Schrotter, G. Towards an Underground Utilities 3D Data Model for Land Administration. Remote Sens. 2019, 11, 1957. [CrossRef]

265. Kisa, A.; Ozmus, L.; Erkek, B.; Ates, H.B.; Bakici, S. Oblique photogrammetry and usage on land administration. ISPRS Int. Arch. Photogramm. Remote Sens. Spat. Inf. Sci. 2013, XL-2/W2, 161-165. [CrossRef]

266. Lemmens, M.; Lemmen, C.; Wubbe, M. Pictometry: Potentials for land administration. In Proceedings of the 6th FIG Regional Conference, San José, Costa Rica, 12-15 November 2007.

267. Luo, X.; Bennett, R.; Koeva, M.; Lemmen, C.; Quadros, N. Quantifying the Overlap between Cadastral and Visual Boundaries: A Case Study from Vanuatu. Urban Sci. 2017, 1, 32. [CrossRef]

268. Koeva, M.; Humayun, M.; Timm, C.; Stöcker, C.; Crommelinck, S.; Chipofya, M.; Bennett, R.; Zevenbergen, J. Geospatial Tool and Geocloud Platform Innovations: A Fit-for-Purpose Land Administration Assessment. Land 2021, 10, 557. [CrossRef]

269. Bennett, R.M.; Pickering, M.; Sargent, J. Transformations, transitions, or tall tales? A global review of the uptake and impact of NoSQL, blockchain, and big data analytics on the land administration sector. Land Use Policy 2019, 83, 435-448. [CrossRef]

270. Van Oosterom, P.; Groothedde, A.; Lemmen, C.; van der Molen, P.; Uitermark, H. Land administration as a cornerstone in the global spatial information infrastructure. Int. J. Spat. Data Infrastruct. Res. 2009, 4, 298-331. 
271. Roić, M.; Vranić, S.; Stančić, B.; Kliment, T.; Tomić, H. Development of Multipurpose Land Administration Warehouse. In Proceedings of the FIG Working Week, Helsinki, Finland, 29 May-2 June 2017.

272. Lemmen, C.; Van Oosterom, P.; Bennett, R. The land administration domain model. Land Use Policy 2015, 49, 535-545. [CrossRef]

273. Crommelinck, S.; Bennett, R.; Gerke, M.; Nex, F.; Yang, M.Y.; Vosselman, G. Review of Automatic Feature Extraction from High-Resolution Optical Sensor Data for UAV-Based Cadastral Mapping. Remote Sens. 2016, 8, 689. [CrossRef]

274. Davidse, J. Semi-Automatic Detection of Field Boundaries from High-Resolution Satellite Imagery; Wageningen University: Wageningen, The Netherlands, 2015.

275. Masouleh, M.K.; Sadeghian, S. Deep learning-based method for reconstructing three-dimensional building cadastre models from aerial images. J. Appl. Remote Sens. 2019, 13, 024508. [CrossRef]

276. Pichel, F. Faster cadastre. RICS Land J. 2018, 2, 12-13.

277. Wassie, Y.A.; Koeva, M.; Bennett, R.; Lemmen, C. A procedure for semi-automated cadastral boundary feature extraction from high-resolution satellite imagery. J. Spat. Sci. 2017, 63, 75-92. [CrossRef]

278. Koeva, M.; Bennett, R.; Gerke, M.; Crommelinck, S.; Stöcker, C.; Crompvoets, J.; Ho, S.; Schwering, A.; Chipofya, M.; Schultz, C.; et al. Towards innovative geospatial tools for fit-for-purpose land rights mapping. ISPRS Int. Arch. Photogramm. Remote Sens. Spat. Inf. Sci. 2017, XLII-2/W7, 37-43. [CrossRef]

279. Fetai, B.; Oštir, K.; Kosmatin Fras, M.; Lisec, A. Extraction of Visible Boundaries for Cadastral Mapping Based on UAV Imagery. Remote Sens. 2019, 11, 1510. [CrossRef]

280. Park, S.; Song, A. Discrepancy analysis for detecting candidate parcels requiring update of land category in cadastral map using hyperspectral UAV Images: A case study in Jeonju, South Korea. Remote Sens. 2020, 12, 354. [CrossRef]

281. Nyandwi, E.; Koeva, M.; Kohli, D.; Bennett, R. Comparing Human Versus Machine-Driven Cadastral Boundary Feature Extraction. Remote Sens. 2019, 11, 1662. [CrossRef]

282. Xia, X.; Persello, C.; Koeva, M. Deep Fully Convolutional Networks for Cadastral Boundary Detection from UAV Images. Remote Sens. 2019, 11, 1725. [CrossRef]

283. Zevenbergen, J.; Augustinus, C.; Antonio, D.; Bennett, R. Pro-poor land administration: Principles for recording the land rights of the underrepresented. Land Use Policy 2013, 31, 595-604. [CrossRef]

284. Enemark, S.; McLaren, R.; Lemmen, C. Fit-for-Purpose Land Administration-Providing Secure Land Rights at Scale. Land 2021, 10, 972. [CrossRef]

285. Törhönen, M.-P. Developing land administration in Cambodia. Comput. Environ. Urban Syst. 2001, 25, 407-428. [CrossRef]

286. .Burns, T. International experience with land administration projects: A framework for monitoring of pilots. In National Workshop on Land Policies and Administration for Accelerated Growth and Poverty Reduction in the 21st Century; World Bank: Washington, DC, USA; Available online: https://www.researchgate.net/publication/228744867_International_experience_with_land_administration_ projects_A_framework_for_monitoring_of_pilots (accessed on 18 October 2021).

287. Arruñada, B. Evolving practice in land demarcation. Land Use Policy 2018, 77, 661-675. [CrossRef]

288. Mourafetis, G.; Apostolopoulos, K.; Potsiou, C.; Ioannidis, C. Enhancing cadastral surveys by facilitating the participation of owners. Surv. Rev. 2015, 47, 316-324. [CrossRef]

289. Chigbu, U.; Bendzko, T.; Mabakeng, M.; Kuusaana, E.; Tutu, D. Fit-for-Purpose Land Administration from Theory to Practice: Three Demonstrative Case Studies of Local Land Administration Initiatives in Africa. Land 2021, 10, 476. [CrossRef]

290. Koeva, M.; Stöcker, C.; Crommelinck, S.; Ho, S.; Chipofya, M.; Sahib, J.; Bennett, R.; Zevenbergen, J.; Vosselman, G.; Lemmen, C.; et al. Innovative Remote Sensing Methodologies for Kenyan Land Tenure Mapping. Remote Sens. 2020, 12, 273. [CrossRef]

291. Williams-Wynn, C. Applying the Fit-for-Purpose Land Administration Concept to South Africa. Land 2021, 10, 602. [CrossRef]

292. Zein, T.A. Fit-For-Purpose Land Administration: An implementation model for cadastre and land administration systems. In Proceedings of the Land and Poverty Conference, Washington, DC, USA, 14-18 March 2016.

293. Hackman-Antwi, R.; Bennett, R.; de Vries, W.; Lemmen, C.; Meijer, C. The point cadastre requirement revisited. Surv. Rev. 2013, 45, 239-247. [CrossRef]

294. Vogiatzis, M. Cadastral Mapping of Forestlands in Greece. Photogramm. Eng. Remote Sens. 2008, 74, 39-46. [CrossRef]

295. Köktürk, E.; Köktürk, A.P. The Role of Photogrammetry and Remote Sensing on Determining the Forest Boundaries and Unauthorized Buildings in Turkey (A Sample Area: Beykoz (İstanbul)). Available online: https://citeseerx.ist.psu.edu/viewdoc/ download?doi=10.1.1.184.1578\&rep=rep1\&type $=$ pdf (accessed on 18 October 2021).

296. Madzharova, T.; Petrova, V.; Ivanova, K.; Koeva, M. Mapping from high resolution data in GIS SOFIA Ltd. In Proceedings of the XXI Congress: Silk Road for Information from Imagery: The International Society for Photogrammetry and Remote Sensing, Beijing, China, 3-11 July 2008; pp. 3-11.

297. Busko, M. Evaluation of the Possibilities to use the Photogrammetric Method to Determine the Course of Boundaries of Cadastral Parcels during the Modernization of the Cadastre. In Proceedings of the 10th International Conference "Environmental Engineering", Vilnius, Lithuania, 27-28 April 2017; Volume 10, pp. 1-8.

298. Chromčák, J.; Šafář, V. The use of aerial photogrammetry in cadastre of real estates. Int. Multidiscip. Sci. GeoConference SGEM 2016, 2, 1035-1041. 
299. Kohli, D.; Bennett, R.; Lemmen, C.; Asiama, K.; Zevenbergen, J. A Quantitative Comparison of Completely Visible Cadastral Parcels Using Satellite Images: A Step towards Automation. In Proceedings of the FIG Working Week, Helsinki, Finland, 29 May-2 June 2017; pp. 1-14.

300. Kohli, D.; Unger, E.M.; Lemmen, C.H.; Bennett, R.M.; Koeva, M.N.; Friss, J.; Bhandari, B. Validation of a cadastral map created using satellite imagery and automated feature extraction techniques: A case of Nepal. In XXVI FIG Congress 2018: Embracing Our Smart World Where the Continents Connect: Enhancing the Geospatial Maturity of Societies; International Federation of Surveyors (FIG): Istanbul, Turkey, 2018.

301. Crommelinck, S.; Lemmen, C.; Kohli, D.; Bennett, R.; Koeva, M. Object-based image analysis for cadastral mapping using satellite images. Image Signal Process. Remote Sens. XXIII 2017, 10427. [CrossRef]

302. Grant, D.; Enemark, S.; Zevenbergen, J.; Mitchell, D.; McCamley, G. The Cadastral triangular model. Land Use Policy 2020, 97, 104758. [CrossRef]

303. Bennett, R.; Kitchingman, A.; Leach, J. On the nature and utility of natural boundaries for land and marine administration. Land Use Policy 2010, 27, 772-779. [CrossRef] 